This item is the archived peer-reviewed author-version of:

Applying SMC pricing in PPPs for the maritime sector

\title{
Reference:
}

Meersman Hilde, Pauw els Tom, Van de Voorde Eddy, Vanelslander Thierry.- Applying SMC pricing in PPPs for the maritime sector Research in transportation economics - ISSN 0739-8859 - 30:1(2010), p. 87-101

Full text (Publisher's DOI): https://doi.org/10.1016/J.RETREC.2010.10.010

To cite this reference: https://hdl.handle.net/10067/847900151162165141 


\section{APPLYING SMC PRICING IN PPPS FOR THE MARITIME SECTOR}

\section{Hilde Meersman, Tom Pauwels, Eddy Van de Voorde and Thierry Vanelslander Department of Transport and Regional Economics University of Antwerp}

\section{Introduction}

Economic research into the seaport sector invariably starts from the port as a physical entity. The role of seaports is described primarily in terms of facilitating the loading and unloading of ships, storage, freight handling (including stripping and stuffing of containers, chemical processing, etc.), and transportation to the hinterland. Clearly, then, port activity is a heterogeneous product, involving various actors. Moreover, port activity is increasingly required to fit perfectly into the logistics chains of which seaports are an integral part.

The objective of each actor as an economic entity is clear to see: to maximise one's own profit by taking adequate account of the principal decision parameters, i.e. price, transport performances (in terms of tonnage and distance), and generalised cost. A shipping company, for example, shall aim for markets where price levels are high enough. And in those markets, that company shall try to maximise its transport performance (measured as tonnage multiplied by distance). At the same time, the shipping company shall strive towards the lowest possible generalised cost. A similar business strategy shall be pursued by all other important actors.

This paper investigates whether Short-run Marginal Cost (SMC) pricing is feasible to implement in seaports and with what type of consequences, e.g. concerning cost coverage. Answering these questions requires an analysis of the cost structure of seaports and especially of seaport calls, as well as of how the division of these costs over the different actors runs. As from the moment that this information becomes available, it can be analysed to what extent SMC pricing can be applied in Public-Private Partnerships (PPP) within the seaport sector. Till now, mainly seaport infrastructure is involved, including the seaport entry from the open sea.

The outline of this paper is as follows. First, the structure of current port pricing schemes is analysed. What differentiation currently exists? What differentiation might be required for SMC pricing? What level of differentiation is possible? What type of information is required to define and/or identify optimal charges? Next follows the calculation of the SMC of a port call. For doing that, attention is paid to the question of short-run versus long-run marginal cost, the calculation principles, the construction and the use of a simulation model. In a subsequent section, PPP agreements in a seaport context are dealt with. 


\section{The structure of current port pricing}

Pricing by ports and operators within ports is historically determined, is often quite complex and, as such, is sometimes perceived as archaic. Debates on overt or covert subsidies, captive markets and the need to constantly dredge and deepen maritime access routes undoubtedly raise questions concerning potential distortion of competition and/or abuse of monopolistic power.

Is it possible to get some typology concerning port pricing? Therefore we should look at pricing of port calls in Europe, especially the current practices, port pricing principles, developments in level of differentiation, and the information required to calculate optimal charges. The emphasis is on the pricing of the arrival/departure of an extra vessel in the port that can be influenced by the port or public authorities, thus focussing on those costs (and, in theory, the incurred prices) caused by that extra vessel. The extra costs caused by the arrival/departure of goods are not taken into account (e.g. terminal handling costs and the applied pricing strategies of port authorities with respect to granted terminal concessions or lease agreements).

\subsection{What differentiation currently exists?}

The port product may be regarded as a chain of interlinking functions, while the port as a whole is in turn a link in the overall logistic chain (Suykens and Van de Voorde, 1998: Meersman, Van de Voorde and Vanelslander, 2009). One of the tasks of the port management authorities consists in providing port and ship efficiency. Pricing can be a tool to improve this efficiency. Generally, port pricing currently differentiates according to the following main criteria (Adler et al., 2003):

- vessel types and destination;

- location of operations in the port territory;

- total time of service use (processing time); and

- season.

This differentiation does not reflect the actual costs incurred by the port operations and does not recover costs, thus creating severe inefficiencies such as congestion as well significant financial loss.

Traditional port pricing is characterised by (Strandenes, 2004):

- non-transparancy (tonnage charges, cargo charges, specific charges,...);

- favouring regional and coastal shipping;

- favouring exports; and

- differentiated cargo charges.

The main criticism of traditional infrastructure charging and cost-based pricing of port services is that they do not induce ship efficiency.

Within ports, the relative importance of the separate links has clearly changed in the course of time, in part because of efficiency-enhancing technological developments (e.g. rising containerisation rate, larger vessels, speedier handling, etc.). This has had, and indeed still has, consequences for the cost structure; for example, in the extent to which economies of scale and costs have been passed on to the various market parties. 
Demand for port calls, port transhipment and supplementary services is derived from demand for the goods involved and is thus a function of economic growth, industrial production and international trade (Meersman, 2009). The prototypical port does not exist. Indeed, no two ports are entirely similar. Ports vary in terms of market players involved (government, port management, shippers, forwarders, agents, shipping companies, trade unions, etc.), each of which has specific objectives. Consequently, the 'port product' is complex and opaque to many. Competition has increased strongly, not just between ports, but also between companies that may or may not be located in the same port (Huybrechts et.al, 2002). Mutual accusations of unfair competition are rife, often resulting in interventions by the regulatory authorities. However, efficient intervention requires insight, particularly into port pricing.

In most European ports, pricing of an additional vessel is based on the sum of several pricing elements, each containing several constituent factors. Some components are shown in Table 1. It is important to point out that discounts (e.g. for frequent users or for passenger ships) and surcharges (e.g. night and weekend shifts) apply on most tariffs. The prices in Table 2 are apparently optional in some ports. This means the services are provided to the vessel operator but they are not mandatory. Tables 1 and 2 are based on current pricing practice in some European ports and should be seen as a summary of individual case studies.

Relatively little empirical research has been conducted on actual pricing strategies by and within ports. One of the few exceptions is the ATENCO project, the main findings of which were presented in Haralambides et al. (2001). The study certainly indicates that there are substantial differences between the respective funding and pricing practices applied in ports across Europe. This diversity is deeply rooted in different legal and cultural traditions and reflects differences in port management style and the related issues of competencies and degree of autonomy.

A first set of results was obtained on the basis of an analysis of survey questionnaires aimed at gathering information on both present pricing principles and strategies, and the likely impact of introducing new pricing systems. The general conclusion speaks volumes (Haralambides et al., 2001, p. 950): "The case studies of ports practising full cost recovery demonstrates the presence of a wide variety of pricing principles used in practice. The pricing strategies of these ports exhibit substantial managerial discretion that cannot be captured fully by textbook definitions of pricing. A best practice formula for pricing in the real world clearly does not exist, not even in ports pursuing full cost recovery as a primary objective".

Trying to formulate a conclusion in relation to the practice of pricing is likely to increase the confusion that already exists. Moreover, it is clearly difficult to outline a typology into which all ports will fit. It appears that the ports that 'preach' full cost recovery do not pass on historical costs, which may be considered as a form of covert subsidising. Thus, research on port pricing behaviour is by no means methodologically sound. 
Table 1. Overview of pricing elements applied in selected European ports ${ }^{1}$

\begin{tabular}{|c|c|}
\hline $\begin{array}{l}\text { HARBOUR DUES / TONNAGE } \\
\text { DUES }\end{array}$ & $\begin{array}{l}\text { - type of vessel; } \\
\text { - gross ton }{ }^{2} \text { (with maxima); } \\
\text { - liner or non-liner shipping; } \\
\text { - } \text { origin and destination of the vessel; } \\
\text { - place of berth in port; } \\
\text { - vessel entering or leaving the port; } \\
\text { - cubic metre indicator; } \\
\text { - weight of goods or number of containers loaded/discharged; } \\
\text { - valid for a period. }\end{array}$ \\
\hline BERTH DUES / QUAY DUES & $\begin{array}{l}\text { - type and length of vessel; } \\
\text { - type and weight/unit of loaded/discharged goods; } \\
\text { - } \text { route of the vessel; } \\
\text { - berthing time; } \\
\text { - gross ton; } \\
\text { - use of quay or buoy; } \\
\text { - cubic metre indicator; } \\
\text { - public or private quay; } \\
\text { - valid for a period. }\end{array}$ \\
\hline TOWAGE & $\begin{array}{l}\text { - location, distance and duration of towage; } \\
\text { - length of vessel; } \\
\text { - gross ton (with maxima); } \\
\text { - type and number of tugs used. }\end{array}$ \\
\hline PILOTAGE & $\begin{array}{l}\text { - point of arrival of pilot; } \\
\text { - draught and length of vessel; } \\
\text { - gross ton; } \\
\text { - distance of pilotage. }\end{array}$ \\
\hline MOORING AND UNMOORING & - length and location of vessel. \\
\hline TRAFFIC CONTROL FEES & - length of vessel. \\
\hline REPORTING OF VESSEL & $\begin{array}{l}\text { - gross tonnage or deadweight of the vessel; } \\
\text { - location of vessel. }\end{array}$ \\
\hline MARITIME POLICE & - gross ton. \\
\hline PORT / TERMINAL SECURITY & - per container or per weight of goods. \\
\hline WASTE DISPOSAL DUES & $\begin{array}{l}\text { - main engine capacity; } \\
\text { - cubic metre indicator. }\end{array}$ \\
\hline PASSENGER FEES & - number of passengers. \\
\hline
\end{tabular}

Source: own composition on the basis of European port information

\footnotetext{
1 Antwerp, Amsterdam, Eemshavn, Ghent, Hamburg, Marseille, Rotterdam, and Wilhelmshaven.

2 "Gross ton: quantity without dimension, used as unit of ship's capacity, as shown in the international certificate of measurement issued in the country of registration in accordance with the stipulations of the International Treaty on Ship's measurement, drawn up in London on June 23, 1969.
} 
Table 2. Some optional pricing elements in the ports

\begin{tabular}{|l|l|}
\hline LOCKING THROUGH OF VESSELS $^{3}$ & $\bullet$ gross ton. (GT) \\
\hline CLEANING OF WATER SURFACE & $\bullet$ length of shift; \\
\hline SUPPLYING DRINKING WATER & $\bullet$ time of cleaning. \\
& • connection charges; \\
\hline WHEELMEN SERVICES $^{4}$ & $\bullet$ water charge. \\
\hline
\end{tabular}

Source: own composition on the basis of European port information

\subsection{What differentiation might be required for marginal cost pricing?}

Several pricing variables were included in Tables 1 and 2 . The prices can currently be levied by port authorities, regional authorities and/or private companies - sometimes on separate invoices. Some benefit might be gained by bringing all the dues into one price-mechanism (= one formula) when a vessel is entering/leaving a port; not only would this be simpler for users, but it would force port authorities to create a greater transparency and lead to greater comparability with competing ports.

From a theoretical perspective, the pricing principle seems simple enough; all tariffs applied by and within the port should be based on the short-run marginal cost. This principle should be adhered to, even in situations where the authorities have made serious mistakes in their investment policy, or where the port is confronted with sudden and unexpected changes in demand. On the other hand, it is sometimes asserted that "from a theoretical perspective, and assuming that a number of conditions are fulfilled, long-run marginal costs represent the most appropriate basis for efficient pricing" (Haralambides et al., 2001, p. 939). The authors go on to say that "irrespective of the cost basis chosen, the principle that prices should accurately reflect (not to say recover) social opportunity costs is crucial" (Haralambides et al., 2001, p. 939; see also Haralambides and Veenstra, 2003).

Whether one should base the port pricing discussion on short run or long run marginal cost, is still under debate. Up to now at the conceptual level short run marginal cost proponents have the upper hand. The argument in favour of the short-term marginal cost is that the whole point of pricing is to confront the user with the additional costs he/she causes. Only the short-term marginal cost indicates precisely the difference in costs between acceptance and refusal of an additional user (Blauwens et al., 2008, p. 427). However, for sound pragmatic reasons, it may be more desirable to charge the long-term marginal cost.

Strandenes (2004) explains how pricing can be used to allocate port slots more efficiently. In the current port pricing schemes, differences in waiting times are not always taken into consideration. This means that willingness to pay is not included. Alternative pricing schemes are: congestion pricing, priority pricing and port slot auctions. It should be added that the alternatives mentioned may be able to improve port efficiency if they can increase effective capacity.

\footnotetext{
${ }^{3}$ Rules of priority (at sealocks) for an entering/leaving vessel.

${ }^{4}$ Assistance to captains.
} 


\subsection{What level of differentiation may be made possible by developments?}

Existing pricing schemes in ports contain already a high level of differentiation (type of vessel, length of vessel, depth of vessel, gross tonnage, weight of goods,...). The question is whether these pricing schemes, which are based on historical costs and trends, adequately reflect the underlying cost structure of an additional vessel entering a port.

Adler et al. (2003, p. 11-12) indicate some key-barriers to implement efficient cost-based pricing in ports:

- lack of transparancy (appearing to be the biggest barrier);

- lack of harmonisation of pricing principles;

- the power of monolithic companies to prevent change;

- ports have little interest in collecting additional data that will be required to accurately charge new tariffs;

- delay data is currently very difficult to compute and scarcity (data) is not considered at all.

Dealing with port pricing, the best approach is to start from the heterogeneous nature of ports, taking into account the different market players, with different - possibly conflicting - interests. Table 3 provides an overview of potential objectives of the various players.

Table 3 Port players and their possible objectives

\begin{tabular}{|l|l|}
\hline Port Player & Possible Objectives \\
\hline Government & Efficient management of assets \\
\hline Economists & Minimising the welfare losses \\
\hline Port authorities & $\begin{array}{l}\text { Maximising throughput } \\
\text { Maximising value added } \\
\text { Maximising employment }\end{array}$ \\
\hline Users & $\begin{array}{l}\text { Transparency of charges } \\
\text { Prices should reflect the costs of the services }\end{array}$ \\
\hline Society & Quality of life \\
\hline
\end{tabular}

Based on Suykens and Van de Voorde, 1998 and Pettersen-Strandenes and Marlow, 2000

Merely on the basis of the potential conflict situations that may arise from these different objectives, we may conclude that "there is no single solution to the problem which is port pricing" (Pettersen-Strandenes and Marlow, 2000, p. 8).

The various possible objectives of the players already indicates the large number of potential incentives to intervene through ports. Some of the observed effects are:

- market imperfections (e.g. asymmetry information, asymmetry in contestability, scale effects in upstream port oriented industries);

- regional economic considerations;

- $\quad$ national economic efficiency (e.g. reducing oversupply of port facilities);

- environmental issues (e.g. obstruction from environmentalist groups against construction of new terminals). 


\subsection{Information required to define/identify optimal charges}

Port pricing remains a complex matter and it is often argued that port accounting systems provide no foundation for any other pricing method than one based on average costs. However, it can no longer be assumed that, even in the absence of 'measurable' marginal costs, approaches based on average costs provide the best approximation to marginal costs.

Port pricing is widely perceived as limited to the dues paid to the port authority or port management for the use of its services. This, however, covers only part of the port picture. Marginal costs encompass a lot more than the costs incurred by the port authority. Moreover, port dues levied by the authority rarely reflect underlying costs, but constitute some arbitrary approximation based on comparison with other ports or on past experience. The fact that they are often not split up according to the services actually used seems to confirm this argument.

An understanding of short term and long term marginal cost components is required. As in other transport modes, one can distinguish between four elements of marginal costs in port operations conceived as a part of the maritime mode: (i) costs for provision of infrastructure, (ii) transport user costs ${ }^{5}$, (iii) costs for supplying port services, and (iv) external costs. In table 4 , some examples of relevant costs are included. Whether they are marginal or not when a vessel is entering/leaving will be discussed in the next paragraph.

Although there is not yet a consensus on how to determine an optimal charge for a port call, some general principles can be outlined. In order to define/identify optimal charges, the following steps can be distinguished:

1. which parties are involved in a port call?

2. what are the competences of the parties involved?

3. which part of the logistic chain should be used ${ }^{6}$ ?

4. taking (1-3) into consideration, which are the relevant costs to be considered?

In other words, it concerns the cost of servicing an additional vessel of a particular type requiring a particular service at a particular time.

The price of a port call should be based on the marginal cost but the discussion remains whether it is better to opt for short term or long term marginal costs for each of the parties and whether to use a-priori or ex-post marginal cost pricing 7 . Another point of discussion is the definition of the marginal unit. Our suggestion is to base the pricing system on one additional vessel calling a port (rather than an extra ton or TEU). This vessel can be described in several ways - gross tonnage, capacity indicator, type of ship, ... or some combination of these.

\footnotetext{
${ }^{5}$ Users in the transportation sector are individual companies desiring to transport commodities.

${ }^{6}$ In other words: where does the principle of marginal cost pricing start? If this principle starts at the beginning of a river leading to a port, the owner of this river should also be involved. For example with reference to the port of Antwerp, dredging the River Scheldt is a combined responsibility of the Flemish Community and the Dutch government.

${ }^{7}$ For example, in the context of dredging, a-priori marginal cost pricing would cover the situation where dredging is done to allow larger vessels to enter the port (i.e. vessels which could not have been there without the dredging), whereas ex-post marginal cost pricing might suffice if an extra vessel entering a port does not cause extra dredging costs.
} 
Table 4 Some relevant port call costs

\begin{tabular}{|l|l|}
\hline Infrastructure costs & $\begin{array}{l}\text { Locks, breakwater, navigation lights, buoys, banks, radar system, dredging, } \\
\text { ice breaking, quays,... }\end{array}$ \\
\hline Transport user costs & Time costs and reliability costs \\
\hline $\begin{array}{l}\text { Costs for supplying } \\
\text { port services }\end{array}$ & $\begin{array}{l}\text { Vessel related costs (tugboat, pilot boat, the vessel transporting } \\
\text { commodities): e.g. fuel, stores, lubricants, spare parts, time costs and } \\
\text { reliability costs for the shipowner,... }\end{array}$ \\
& $\begin{array}{l}\text { Service related costs: vessel manning costs, shipping agency, ship } \\
\text { repair and cleaning, supply of fresh water, supply of energy, supply } \\
\text { of mariner's care, waste reception, bunkering, port authority,... }\end{array}$ \\
\hline External costs & $\begin{array}{l}\text { - Accident costs; } \\
\text { - Noise costs; }\end{array}$ \\
& $\begin{array}{l}\text { Air pollution costs; } \\
\text { - Congestion costs. }\end{array}$ \\
\hline
\end{tabular}

Source: own composition

As a next step, the following partners involved in a port environment should be distinguished:

- Supervising government(s);

- Port authority;

- Terminal operating companies (handling and storage);

- Other port users (shipping companies, industrial companies, shippers, hinterland transport companies);

- Service providers (pilots, towers, customs brokers, agents, forwarders, ship repairers, stores/lubricants providers, bunkering providers, waste reception providers); and

- The society.

For each of those parties, the relevant marginal costs for a port call will need to be calculated and their ability to charge other parties will need to be determined. A specific question will then be which party(s) will charge (directly or indirectly) the owner of the vessel entering the port, i.e. the vessel generating the marginal costs.

In the next paragraph, the following questions will be investigated for each of the parties:

- what marginal costs do they experience when a vessel is entering/leaving a port?; and

- are those marginal costs relevant for the pricing strategy in the context of a port? 


\section{Calculating the social marginal cost of a port call}

First of all the discussion 'short-run versus long-run' will be dealt with. Consequently, in order to determine optimal charges for a port call, it is necessary to decide what part of the logistic chain is deemed to be part of the port call. Having done this, it will be necessary to identify the costs of servicing an additional vessel of a particular type requiring a particular service at a particular time. These will include: infrastructure costs, transport user costs, costs for supplying port services, and external costs.

\subsection{Short-run versus long-run?}

An important element is to clarify the principle of marginal cost pricing in its application within a port context. The marginal cost rule states that transport should be provided at a price that reflects exactly the marginal cost, i.e. the price should be equal to the cost of the resources absorbed in producing an additional unit of the service. At a price above (below) marginal cost production will be lower (higher) than the optimal level.

Starting from this general principle, the question arises what marginal cost is appropriate to be considered in a port context: short-run, long-run, medium-run, or some combination of the former? According to several authors only a conditional answer can be given to this question ${ }^{8}$.

Short-run marginal cost relates to the use of existing capital goods, while long-run marginal cost not only relates to the use of existing capital goods but also to the expansion of capital goods in order to keep up with output. That means that the long-run marginal cost contains the cost of additional capital goods as well as the cost of transport services to materialize with these capital goods.

In an ideal situation with perfect competition, the price will be equal to the long run marginal cost and the long run average cost. This is illustrated in Figure 1. The short run marginal (SRMC) and average (SRAC) cost curves reflect the cost structure for different scales of production. The long run average cost curve (LRAC) is the envelope of the SRACs. The long run marginal cost curve (LRMC) intersects the SRMC at a production level for which the SRAC $=$ LRAC. At production level $\mathrm{Q}^{*}$ and price $\mathrm{P}^{*}$ resources are used in the most efficient way and there is also full cost recovery.

\footnotetext{
${ }^{8}$ This paragraph has been based on the port and transport economics literature (e.g. Bennathan and Walters, 1979; Blauwens, De Baere and Van de Voorde, 2008) and on discussions with colleagues. We explicitly would like to thank Prof. G. Blauwens, University of Antwerp, for his comments and suggestions. All eventual, remaining errors are our responsibility.
} 


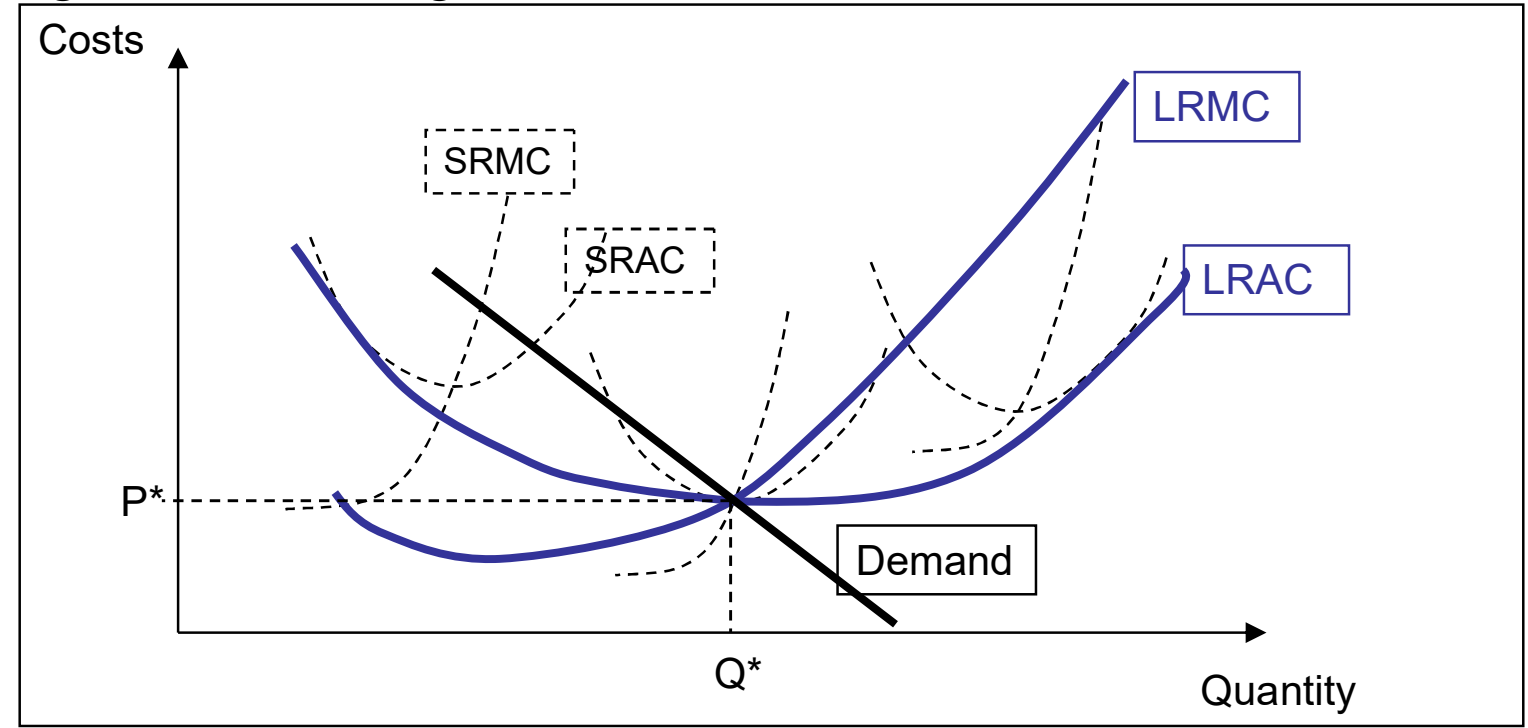

Source: own composition

This analysis not only assumes perfect competition, but also a perfect knowledge of the long run demand function and also a fast and almost continuous adjustment of the capacity or the scale of operation. Investments in port infrastructure however are not only expensive, but it also takes time to implement and for the investment projects to materialize. Furthermore, short run demand can differ considerably from the long run demand projections. As a consequence, one can be confronted with situations of under- or overutilization of the existing capacity. As a result, the short-run marginal cost may either be lower or higher than the longrun marginal cost (see Table 5).

Table 5 Relation between short- and long-run marginal cost in a port context

\begin{tabular}{|l|l|l|}
\hline Scenario & Effects on cost & Effect of pricing \\
\hline $\begin{array}{l}\text { High capacity } \\
\text { utilization, e.g. } \\
\text { demand is higher } \\
\text { than forecasted } \\
\text { and/or lack of } \\
\text { capacity (Figure 2) }\end{array}$ & $\begin{array}{l}\text { The short-run } \\
\text { marginal cost will be } \\
\text { high (cf. scarcity of } \\
\text { port capacity) and } \\
\text { above the long-run } \\
\text { marginal cost }\end{array}$ & $\begin{array}{l}\text { With a price close to the long-run } \\
\text { marginal cost (Figure 2, point a), } \\
\text { congestion would occur; with a price } \\
\text { based on short-run marginal cost (Figure } \\
\text { 2, point b), congestion would be virtually } \\
\text { eliminated. } \\
\text { Full cost recovery. }\end{array}$ \\
\hline $\begin{array}{l}\text { Low capacity } \\
\text { utilization e.g. } \\
\text { demand is smaller } \\
\text { than expected and/or } \\
\text { excess capacity } \\
\text { (Figure 3) }\end{array}$ & $\begin{array}{l}\text { The short-run } \\
\text { marginal cost is } \\
\text { below the long-run } \\
\text { marginal cost }\end{array}$ & $\begin{array}{l}\text { With a price based on the long-run } \\
\text { marginal cost (Figure 3, point a), the use } \\
\text { of the already underutilized port would } \\
\text { be discouraged. With a price based on the } \\
\text { short-run marginal cost (Figure 3, point } \\
\text { b) there will be a higher capacity } \\
\text { utilization. } \\
\text { No full cost recovery. }\end{array}$ \\
& &
\end{tabular}

Source: own composition 


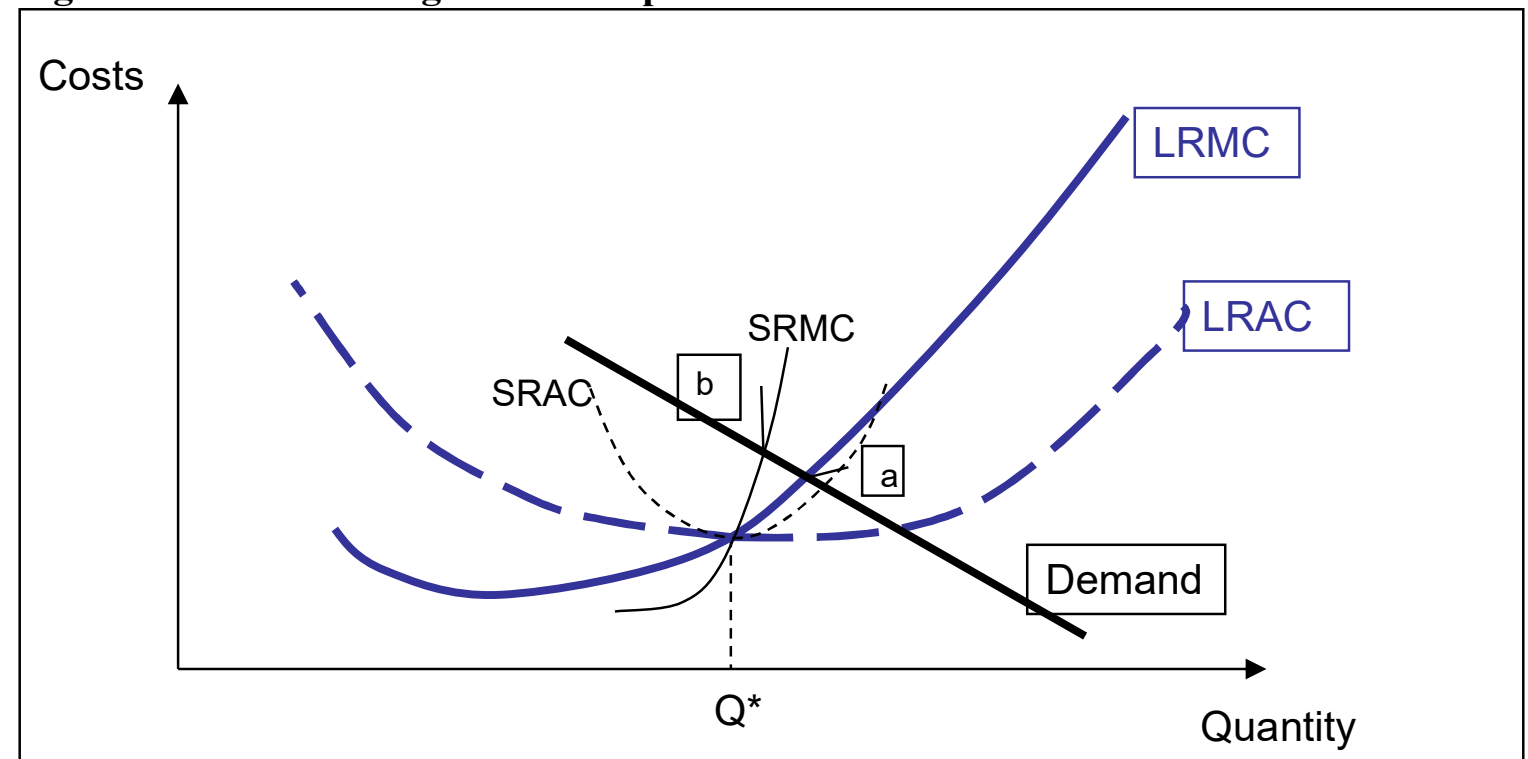

Source: own composition

Figure 3 Demand is smaller than expected: SRMC $<$ LRMC

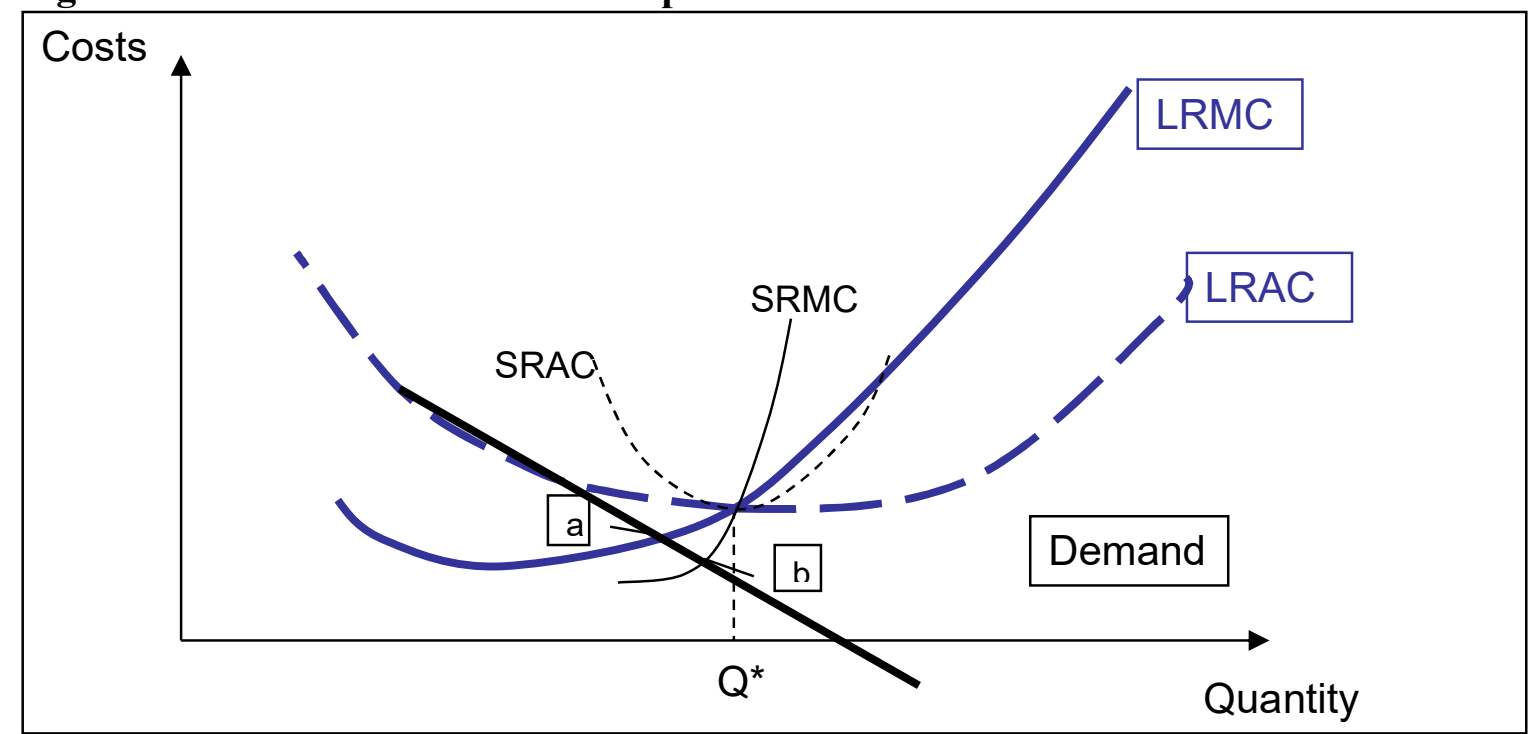

Source: own composition

Out of this one can conclude that the short-run marginal cost is always the appropriate base for pricing, irrespective of having under- or overcapacity. The aim of pricing is to confront the user with the additional costs that he/she causes. Only the short-run marginal cost indicates precisely the difference in costs between acceptance and refusal of an additional user.

Sometimes it may make sense to charge for the long-run marginal cost. If one equates prices to the short-run marginal cost, we risk to get strong variations over time, with different rates for peak and off-peak periods (e.g. function of tides), different prices in the high and the low 
season. Moreover, transport prices will also fluctuate over the years. With growing demand, prices will increase, up to the point when an investment is made in new capital goods, after which prices will suddenly decline ${ }^{9}$. Such a strong differentiated and fluctuating tariff, though desirable from the perspective of economic allocation, may meet with resistance for political and/or organizational reasons. It may therefore be deemed necessary to impose prices that remain constant. This price should then be a kind of average of the short-run marginal cost at different moments. This average can be approximated by the long-run marginal cost.

\subsection{Calculation principles}

A seaport, for the purposes of this paper, is defined according to the nature of the vessels entering the port: if sea vessels can reach the ports, they are to be considered as seaports. Four main cargo types using seaports can be distinguished: containers, general cargo, liquid bulk and dry bulk. Also passenger vessels call at seaports. Different commodity types will imply different commodity values and therefore also different levels of marginal costs.

The route of a vessel calling at a seaport can be divided into several stretches. Figure 4 shows a general overview of such seaport setting. A vessel that is on its way to a port can sail on several stretches, depending on the port setting as well as on its own characteristics or on environmental factors: starting with maritime transport at sea, a part of a river or canal can be used, further on also a lock, and finally docks will be reached. Once the ship is berthed, other activities can continue: terminal activities such as unloading/loading, storage and unloading/loading of hinterland modes. After this, the goods transformed will be moved to hinterland connections.

\section{Figure 4 Theoretical seaport setting}

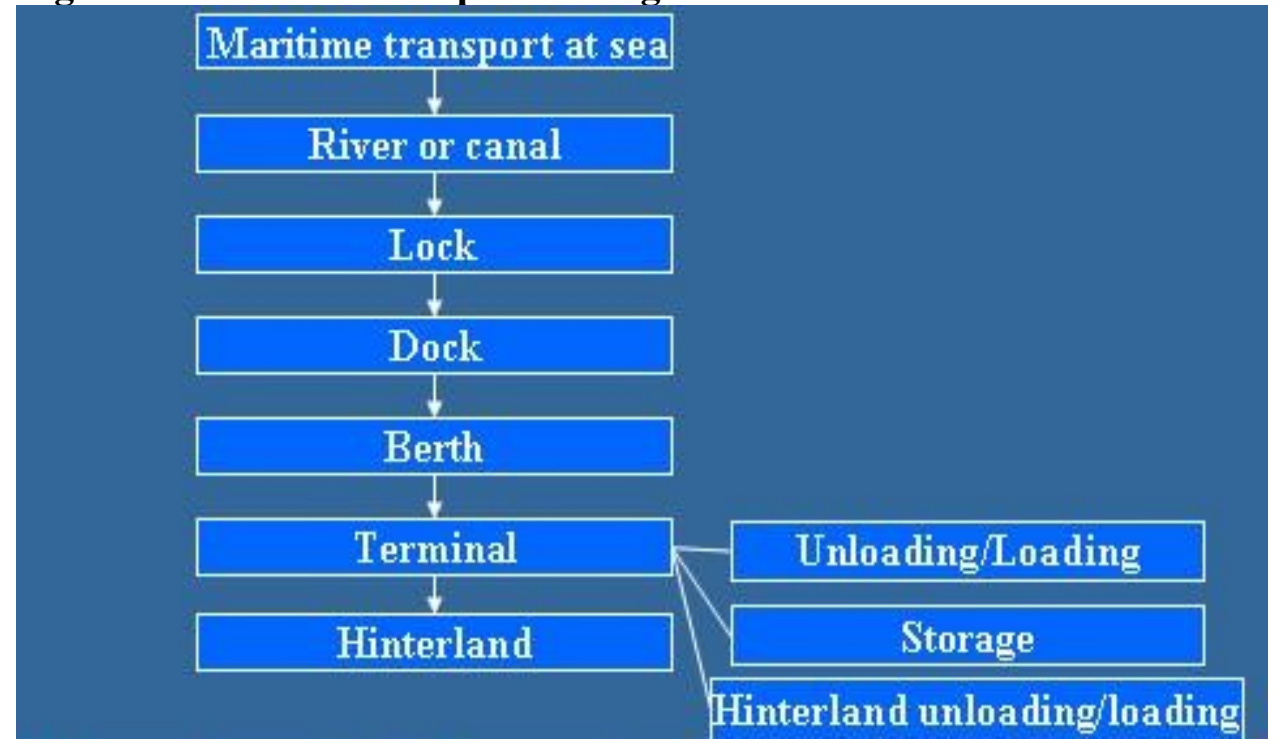

Source: own composition

\footnotetext{
${ }^{9}$ A typical characteristic of a port is that port expansion takes a long time (in some cases several years) and in construction and operations there may be large discontinuities. In case of this kind of discontinuous jumps (e.g. the new Deurganck container terminal in the port of Antwerp adds a capacity of 6 million TEU, be it in stages), the long- and short-run marginal costs will coincide for wide ranges of output from the same size of port or terminal. Pricing based on long-run marginal cost can be acceptable for all outputs if one does not operate too small or too large a port or terminal.
} 
It is of course also possible to focus on movements in the opposite direction. The seaport setting is a general typology and can be applied to freight vessels and passenger vessels. It is of course not necessary that every link is used in a specific port typology. Not all ports have locks for instance.

Figure 5 represents the possible stretches graphically, and indicates where waiting may be imposed. Full lines indicate sailing time, dotted lines indicate waiting or idle time. The length of the various stretches as represented may vary of course according to the port's specific setting. The vessels graphed on the picture indicate pilotage and/or towage, which may be required by law or requested by the vessel itself. A distinction should be made among sea pilotage and towage, river pilotage and towage, canal pilotage and towage, and in-port pilotage and towage. Not every intake of pilots or towage vessels requires the vessel to stop: in some cases, pilots may for instance enter the vessel while the latter is sailing.

\section{Figure 5 Graphical structure of a seaport call}

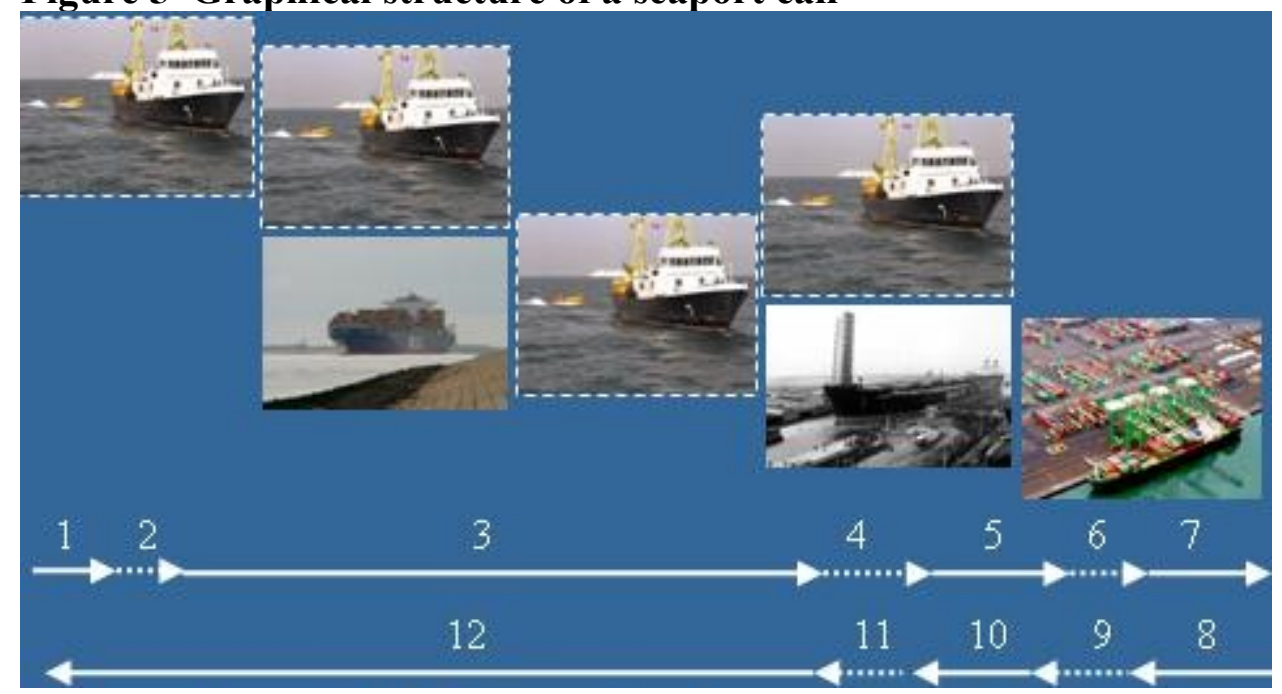

Source: own composition

It should be noted that one or more of these regular stretches may be interrupted by for instance a call at another port located on that stretch, or by for instance a bunkering or repair call. Some ships also call at several terminals at a time. In that case too, the normal times of a single berth call will be exceeded.

This section details what marginal cost elements can be distinguished in such theoretical seaport setting, what port settings can be distinguished in practice, and what vessel types imply substantial differences in marginal costs. Assessing marginal costs this way should ultimately allow determining prices which equal marginal costs, and particularly short-run marginal costs. Considering short-run marginal costs implies that derived effects on for instance shippers (mainly time and reliability effects), long-run capital investments (vessels, deeper maritime entrance, larger locks, more berths, more recent handling cranes) and loss of port's or even shipping companies' customers are not considered, although the methodology allows to include them in a next phase. 
Four main components of marginal costs can be distinguished:

- Infrastructure costs, related to e.g. wear and tear of the locks.

- Transport user costs, related to e.g. the operations of vessel calling.

- Supplier/operating costs, related to e.g. the operations of the locks.

- External costs, related to e.g. accidents or pollution.

This categorisation is founded on the results of the UNITE-project (Bickel, a.o., 2000, p. 7), which was also stated to be a suitable composition in earlier studies (Talley, 1994, pp. 67 70; European Commission, 1998, p. 10).

We observe that sometimes, port administration is considered as a separate dimension of supplier/operating costs. In the meantime, it is reasonable to omit commercial port costs in the marginal context. There is no clear link between commercial costs and an extra ship entering a port. A small port, aiming at a larger market share, may use extensive marketing and promotional tools, causing an inverse relationship with existing traffic. It may also be possible that a large port uses its widespread fame as a commercial tool, so that an extensive marketing campaign is not necessary. Also, a port may use pricing incentives as an indirect promotional aid. All these factors cause the relation between commercial costs and number of vessels calling to be unpredictable. As staffing is usually fixed, or at least not directly related to the number of vessels entering a port, port administration staff costs do not have to be considered to be a marginal cost element either. A supplementary service cost item is constituted by port authority offices, where a similar argument is valid: there is no periodic replacement. The absence of a direct link of replacement with number of ship calls explains the omission of this cost element in our calculations.

An important supplementary service both to vessel and goods, especially as intermediation between shipowner and transport user is concerned, is shipping agency. As the agent is only to be paid when the deal is made and so the ship is certain to sail, his commission is to be considered as a purely marginal cost. Peston and Rees (1971, p.12) stress the importance of this cost item. However, as it is mainly a derived activity, which should not necessarily take place in the port of call, especially with new developments such as internet and e-business, it is not dealt with in this paper.

A further supplementary service specific to the vessel is ship repair and cleaning. This entails hull blast, cleaning and repair, steel replacement, and dry-docking in general. Again, workers' wages could be retained as marginal costs (Stopford, 2009). However, as these are activities not strictly necessary for a ship call, they are not included in the marginal cost calculations made in this paper.

Finally, other supplementary services to vessels are energy supply, fresh water provision, medical care, waste reception and bunkering. Energy supply is rare, since most vessels have their own generators on board in case they need energy. Fresh water for use on board is either supplied through fixed waterpoints, located at regular distances on the quay, or brought with waterboats. Mariner's care is supplied in a specially equipped office which is manned at any time. This means that energy, water and care supply do not cause any marginal staff costs, except for the case of water provision with water boats, where workers are eventually to be hired for that specific purpose and vessel. As this involves a supplementary service however, it is not considered in this paper. Waste reception is performed for each ship individually on explicit demand. In that case, a container is put, where all waste can be collected. This way, waste reception has marginal staff costs, as containers have to be transported to each ship. Moreover, a ship is not obliged to use waste reception facilities. If a certain port is the last 
port in a number of calls at European ports, the probability that waste will be kept till that port is low. Bunkering finally is also to be performed on a ship-to-ship basis. Bunkering is done by boat by private companies, which means that extra crews need to be available for servicing an extra ship, which implies marginal costs.

Marginal superstructure costs for water, energy and mariner's care supply are zero. Waste reception just like bunkering is performed for each ship individually, but vessels are part of a fixed fleet owned by several private companies. Marginal superstructure costs for bunkering and waste reception do not exist therefore.

Anchorage is an activity for which many ports charge, but which does not cause any direct (marginal) cost. Therefore, it is not considered as a marginal cost element in the analysis of this paper.

Accidents deserve special attention in the further analysis of this paper. Need for marginal cost calculation in this area is expressed by Tervonen a.o. (2001, p. 42): "The aim of accounting for marginal accident costs of transport is to pass the external social costs of accident risks caused by additional movement on to the users of the network as such. Risk costs must be determined for all categories of transport activity and for different transport environments ex ante, along with the resulting realisation of ex post real economic costs. The limiting factor of costing is the primitive level of understanding and lack of applications in risk-related marginal cost assessment."

A distinction is made for direct accident costs between material damage and human damage. This is also the categorisation used by Tervonen a.o. (2001, p. 43): "Accident costs fall into two categories: 1) purely financial, medical, repair and production loss costs, and 2) the nonmaterial costs of injuries and suffering. These cost items should be analysed together with risk factors for defining probable costs of the actualisation of risks".

Material damage has to do with the vessel (extra replacement) as well as with loading/unloading or storage (extra repair of superstructure) operations. Material damage comprises damage to proper capital goods (for vessel operators and superstructure owners) as to capital goods of third persons (especially for vessels). Furthermore, damage to transported goods is part of material damage costs.

For human damage, the same distinction is made: accidents can happen on board of the vessel as well as on the landside. With human damage, both damage to proper workers as to passengers is considered. Dutch Port Council has dedicated a special report to port accidents (Nationale Havenraad, 2001). They also distinguish between shipboard risks (from unlashing / lashing or from removing / installing conventional twistlocks) and quay-side risks (from removing / installing semi-automatic twistlocks). Experience from Tervonen (2001, p. 8) learns that "accidents with fatality or injury are rare in commercial services". For completeness though, we retain the maritime part in the marginal cost categorisation.

In each case, the increased probability of an accident by an extra vessel calling has to be calculated. This way, marginal accident costs caused by an extra vessel can be quantified.

Framework specifications about marginal supplier/operating costs are largely present in literature. In most cases though, a specific point of view is taken (shipowner, cargo handler,...), and stress is put on income and expenses instead of revenues and costs. Costs 
need not be monetary expenses, while revenues need not strengthen the company's cash position. Most references take the shipowner as a central player. In some of these cases (e.g. Stopford, 1997, pp. 154 - 171; Wijnolst and Wergeland, 1997, pp. 204 - 226), the maritime part as well as the port part are considered. Other references (e.g. Heggie, 1974, p. 3; Peston and Rees, 1971, p. 12) specifically concentrate on port expenses from the point of view of the shipowner. Talley (1994, p. $67-70)$ is even further decomposing each port expense item. In this paper, the stress is clearly on costs, and in particular all costs caused by a marginal vessel call.

The different stretches composing a port call are now assessed in further detail (the numbers refer to figure 5).

(1) For the at-sea stretch, there are no marginal infrastructure costs. Ice breaking is checked for the Port of Helsinki. In a normal winter, ice breaking is usually to be performed once in the morning, and once in the late afternoon, before the last group of vessels is leaving. It is clearly stated that ice breaking is ship-independent. Even in case no ship would be expected to call at the port, ice breaking is performed on a regular time basis. This is necessary among others to allow rescue operations to take place. So the marginal cost of ice breaking is zero. When a strong winter occurs, ice breaking has to be performed on a more frequent basis, in some cases even nearly for every ship or for every group of vessels (vessels are sometimes grouped in convoys then). But this situation is a strong exception, so we consider marginal ice breaking costs not to exist.

Transport user costs have a marginal component which mainly consists of vessel operating costs. The latter costs are composed of the elements from table 5.

Table 6 Marginal vessel operating cost elements

\begin{tabular}{|ll|}
\hline $\begin{array}{l}\text { Marginal cost } \\
\text { elements }\end{array}$ & Function of \\
\hline Crew & flag, vessel type and size, time,... \\
Fuel & $\begin{array}{l}\text { vessel type and size, distance, speed, } \\
\text { cargo load... }\end{array}$ \\
Vessel type and size, time,... \\
Stores & Vessel type and size, distance, \\
Lubricants & speed,... \\
Spare parts & Vessel size and type, distance, \\
& speed,... \\
Oil & Vessel size and type, distance, \\
& speed,... \\
\hline
\end{tabular}

Source: own composition

Pilotage and towage may be required, depending on environmental as well as ship characteristics. For pilotage and towage, in general, there is only need of supplementary tugboats and pilot boats in case capacity is exceeded. Most pilotage and towage companies have a fixed fleet. They theoretically never go beyond this fleet by hiring material. The same reasoning goes for pilotage and towage staff. This way, the extra ship calling does not cause any supplementary capital costs for towing nor pilotage. The only marginal cost items on the supplier/operator side are therefore related to fuel use, oil consumption and spare parts requirements. Meanwhile, tugboats are also used as rescue 
and fire-fighting boats. They are used as buoy-layers too. The latter functions therefore have no marginal component.

Accidents are an important external element at sea. Their marginal cost level is a function of flag, total traffic, traffic conditions,... Air pollution and water pollution are other external elements, which are dependent on vessel size and type as well as speed,... Eventually, also pilotage may be needed and therefore have a marginal component. Noise effects are negligible in this section.

(2) At the point where ships have to wait to enter the river or canal, the only infrastructure element which could imply marginal costs are buoys, which are especially necessary to trace out the channel at sea. However, they are replaced on a regular basis. Neither their number nor the regularity of replacement is influenced by the number of vessels. Regularity solely depends on time: about every 18 months, a buoy has to be replaced, since by that time, natural overgrowth makes buoys less visible, so that maritime safety is negatively influenced and replacement is needed.

Transport user costs at the buoy waiting point are the same as those described in Table 6, be it that there is no fuel consumption, no oil consumption, and no need for spare parts. They are therefore called 'limited' vessel operating costs.

As to the supplier/operator costs, towage is not needed for the waiting process, and pilots usually only come on board when the ship is taking off for the canal entry.

Accidents in this zone are extremely limited in number and impact, just like noise pollution. Air and water pollution are possible, although less likely than at full sea, as control at this point is usually much more tight.

(3) In the zone from buoy to lock, no infrastructure elements have marginal components in a ship call. Breakwater expenses are considered to be independent of port usage (common costs, cfr. Heggie, 1974, p. 14). The same holds for navigation lights, which is confirmed by the European Commission (1998, p. 10). For buoys in the buoy-to-lock zone, the reasoning for the maritime entrance waiting point is valid here too. For maritime entrance banks, replacement does not seem to depend on the number of vessels passing by. Much more important is the natural streaming of the water: certain points of the bank need to be regularly fortified. This way, Flemish Department of Environment and Infrastructure states that marginal bank costs should not be considered. ${ }^{10}$

The radar system in the buoy-to-lock zone is a unique investment, the capital cost of which is not influenced by an extra ship entering or leaving the port. Radar towers are often built alongside maritime entrance rivers. Data are processed at a central tower. From there, control is assured through several screens operated by a fixed staff. In case a dangerous situation tends to occur, direct contact can be made with the ship(-s) involved. This process implies that nowhere marginal costs are in place.

Concerning infrastructure maintenance, just like bank erosion, dredging is a cost item which is only linked with time and streaming of the river, and not with the number of vessels calling at the port. Short-run marginal costs of dredging are zero.

\footnotetext{
${ }^{10}$ Confirmation of this statement is found on the web site of the Scheldt Information Centre (2006).
} 
Vessel operating costs, as transport user costs, do have a marginal component. The full set of vessel operating costs, similar to that of Table 6, applies.

Pilotage and towage are often required here, so that there too the marginal elements discussed in the supplier/operator part of the at-sea section apply.

On the side of external costs, air pollution applies. Its cost can be assessed in a way similar to that of the at-sea section. Noise effects are negligible again. Accidents have an extremely limited chance of occurring, as pilotage and towage are provided and in many cases made compulsory. Water pollution is minimal too, as port state control is in place.

(4) In the locking zone, from an infrastructure point of view, it should be noted that lock replacement is not dependent on the mere time factor, but is determined by the number of moves lockdoors have to make. This way, marginal lock costs are not directly caused by an extra ship but by a group of vessels. Locks have a fixed capacity, which is not always fully used. As a solution, we can take the average occupancy rate for our calculations. By spreading the marginal lock replacement cost over this average number of vessels per move, we have a method which allows to state that lock replacement has a marginal cost per vessel. Spreading over vessels in the lock can be done on an equal basis, ignoring for pragmatical reasons the fact that different types (length) of ship may be present.

It is furthermore correct to state for locks that maintenance, just like replacement, is a function of the number of moves (groups of vessels), and so depends on the call of individual vessels. Marginal lock maintenance costs should again be spread over the vessels in the lock at one move, in order to obtain marginal costs for a vessel.

Among the transport user costs, limited vessel operating costs like in section (2) of the port call apply.

On the supplier/operator side, in locks, usually, the river or canal pilot leaves the vessel at the moment that the vessel moors into the lock, whereas the port pilot, if required, boards the vessel at the moment that the vessel starts heading towards the berth. Therefore, no pilot costs are involved in the stretch where the vessel is waiting in the lock.

On the external side, noise, air and water pollution are extremely limited, as engines are usually switched off while in lock. Accidents in or around locks, due to the special guidance measures, are normally restricted to the absolute minimum.

(5) In relation to infrastructure in the lock-to-berth zone, Heggie (1974, p. 13) states that quay maintenance is independent of the number of vessels calling at the port, and this way doesn't have a marginal cost component. Wear and tear is not determined by the number of vessels passing by, but rather by weather conditions and type of building material. $^{11}$

Among the transport user costs, the vessel operating costs should be considered. They are similar to those of Table 6 , with the difference that in this section diesel oil is used instead of heavy fuel, as the former is less polluting.

\footnotetext{
${ }^{11}$ This is confirmed by the White Paper of the European Commission (1998, p. 10), where maintenance of this type is considered to be a fixed cost.
} 
Supplier/operator costs are mainly composed of pilotage and towage costs, at levels comparable to those in preceding maritime entrance sections.

External costs mainly show up in air pollution, be it that the latter is usually smaller than at sea, as different fuel is used. Water pollution is rather exceptional due to port state control. Noise effects are negligible again. Accidents are not at all frequent too, as pilotage and towage are present.

(6) For the at-berth section, it was stated in (5) that quay wear and tear is not determined by actual use, but rather by 'external' conditions. Therefore, it should not be included as a marginal cost element in the setting of this paper.

Transport user costs are the limited vessel operating costs which also applied to (4) in the lock zone. There are no marginal supplier/operator costs involved, as ships in this stretch are just waiting to be operated. For the same reason, accidents as well as noise, air and water pollution are all absent.

(7) The observations made in (6) with respect to quay wear and tear and transport user costs also apply to stretch (7).

Manning of the cargo handling superstructures (cranes, straddle carriers,...) are considered to be of marginal nature too: if handling material is not operating, employees need not be paid. By extension, this is also true for port workers doing hands work. It is also valid for passenger handling, where employees have to guide and welcome travellers. Handling is closely linked to storage. Storage personnel's wages are of the same marginal nature as the previous manning costs.

Handling operations causing marginal wage costs are the transfer from vessel to yard and the transfer between yard and terminal gate in the case of commodities. In the case of passengers, this is usually one move. Lashing / unlashing, hatch moving and weighing are additional operations which cause marginal staff costs. Container storage is mainly composed of stacking containers or stocking commodities. Cargo planning is considered to be done on an administrative level, with employees not assigned to a specific ship but doing a job for several vessels. Therefore, the latter's cost is not marginal (Ocean Shipping Consultants, 2001).

Handling costs are heavily dependent on the type of goods transported. Therefore, a distinction between different commodity types (and corresponding ship types) will have to be made. Handling superstructure mainly is of capital nature. First of all, cargo and passenger handling facilities (e.g. cranes and straddle carriers) are to be in place. Since this type of capital is usually not to be replaced after a certain number of moves, it does not have a marginal cost component. Just like for ship fleet, we assume that a fixed amount of capital equipment is disposed of, and that no use is made of external material. If extra handling material would be used, beyond the fixed fleet available, and corresponding operators, beyond the fixed number of people employed, would have to be temporarily hired, extra capital hiring costs would constitute extra marginal costs.

It should be remarked that sometimes terminal productivity is enhanced on explicit demand of the shipowner. Higher productivity means more moves per hour and per crane, 
mostly through extra resources. These surely have a marginal cost, and therefore, the simulation will have to sort out situations with 'normal' superstructure and staffing levels from situations with increased productivity requests.

Next to handling, also storage has to be provided. For storage areas and warehouses, even less than for handling superstructure, use-dependent replacement is required.

Warehouse energy and surveillance are to be considered as fixed costs, independent of the volume of commodities stored. Surveillance is assured anyway. Energy costs are highest for getting base temperatures in warehouses. The marginal energy use for supplementary volumes which have to be cooled can be neglected. This means that marginal operating costs for warehouses are non-existing.

Accidents at the berth or on the storage area are more frequent than in the maritime entrance or on the lock to berth area, but in most cases cargo loss and especially human damage is much more important than material damage to the container or to handling material. In case an accident happens, marginal costs are of course involved. Noise and air pollution are present in this stage too, but are mainly caused by handling superstructure instead of the vessel, as the latter normally has its regular engines switched off.

(8) This stretch is the prolongation of stretch (7), be it with a perspective on returning to full sea. Marginal costs therefore correspond to those of stretch (7).

(9) Stretch (9), which is the zone of time where the vessel waits before leaving the berth and eventually also the port, equals stretch (6).

(10) Stretch (10), and therefore also the composition of its marginal costs, is similar to stretch (5), in the sense that the vessel is now moving from the berth towards the lock.

(11)This stretch is the equivalent of stretch (4), where the vessel is going through the lock process.

(12) This final part of the port call corresponds to stretch (3) and finally ends into reaching the full sea, where the vessel starts heading for its next port of call.

It is important to observe that stretches in one direction can incorporate time use which may differ a lot from time consumption in the opposite direction. Neither should time use at one particular call equal time use at another call for the same stretch, even if the same vessel is involved: different 'environmental' circumstances may apply.

The occurrence of the previous stretches, each of them having corresponding marginal costs, determines the port lay-out. Port lay-out is one of the characteristics which allows distinguishing among port types. Other main distinguishing characteristics, which are drawn from Vanelslander (2005) are mentioned in Table 7. 
Table 7: Seaports' main distinguishing factors

\begin{tabular}{|ll|}
\hline Factor & Possible states \\
\hline Activity scope & Complete - limited \\
\hline Lay-out & Tidal - non-tidal; basins - no basins \\
\hline Location & Coastal - river; large - small population hinterland \\
\hline Organization & Land lord - limited operating - operating \\
\hline Security & High - moderate - low \\
\hline Traffic & High - moderate - small; mixed - containers only - bulk only \\
\hline
\end{tabular}

Source: own composition

Most combinations of variables' values are possible, although some combinations have a more frequent occurrence than others.

But not only a different port setting makes up for different marginal costs. Also the type of vessel is important. A first characteristic to distinguish among vessel types is the type of cargo transported. In the beginning of this section, a distinction was made between containers, general cargo, dry bulk, liquid bulk and passengers. For each of these vessel types, a further distinction is possible according to the size of the vessel. As an illustration, Table 8 distinguishes among the most frequent container vessel sizes in general.

Table 8. Most frequent container vessel sizes

\begin{tabular}{|c|c|c|c|}
\hline Container vessel category & $\begin{array}{c}\text { Average TEU } \\
\text { capacity }\end{array}$ & $\begin{array}{c}\text { Typical length } \\
(\mathrm{ft})\end{array}$ & $\begin{array}{c}\text { Typical draught } \\
(\mathrm{ft})\end{array}$ \\
\hline 1st generation & $1,700 \mathrm{TEU}$ & $450-630$ & 7 \\
\hline 2nd generation & $2,305 \mathrm{TEU}$ & 700 & 17 \\
\hline 3rd generation (Panamax) & $3,220 \mathrm{TEU}$ & $860-950$ & 38 \\
\hline $\begin{array}{c}\text { 4th generation } \\
\text { (Post-panamax) }\end{array}$ & $4,828 \mathrm{TEU}$ & $900-1,000$ & 42 \\
\hline $\begin{array}{c}\text { 5th generation } \\
\text { (Post-panamax-plus, jumbo, } \\
\text { ultra-large container vessels, } \\
\text { mega-containerships) }\end{array}$ & $7,598 \mathrm{TEU}$ & 1,100 & 46 \\
\hline \hline
\end{tabular}

Source: own composition

A specific application of marginal cost calculation could be the consequences of congestion (if existing). It speaks for itself that congestion will have a detrimental impact on the generalised cost and on the overall transport or throughput performance. After all, to a shipping company, congestion implies time loss and thus a higher generalised cost. However, congestion is also problematic for the other port actors. Vessels whose arrival at berth is delayed through congestion may be difficult to fit into the loading and unloading schedule of the terminal operator. This will have implications for capacity management and result in higher costs. The same holds for other actors, including in the fields of storage and hinterland transportation. Moreover, a knock-on effect may be felt elsewhere in the maritime transport chain: delays can have an impact on operations in other ports of call. Therefore, it is important 
that we should acquire adequate insight into how port congestion arises, the associated costs, and how it can be avoided or eliminated most effectively.

\subsection{Constructing a simulation model}

The aim of building and using a simulation tool is to calculate the marginal cost of a port call. The emphasis is on the arrival/departure of an extra vessel in the port. To be able to construct a simulation tool, it is first of all necessary to define which parts and which activities of the total logistics chain are considered. This has been done in paragraph 3.2. ('calculation principles').

Within the simulation tool, the calculations are based on the inner box of Figure 6: river or canal, lock, dock and berth. We do not include maritime transport at sea, terminal activities and hinterland movements. The loading/unloading activities of the vessel are only considered in relation to the crew members and not in relation to terminal workers. The starting point can be defined as the first contact point of the vessel with the port, in case a vessel is arriving. The ending point can be defined as the last point of contact of the vessel with the port, in case a vessel is leaving. Confining to this part implies that noise costs, which are only caused by terminal superstructure, are not treated in the calculations.

\section{Figure 6 The seaport simulation framework (based on Figure 4)}

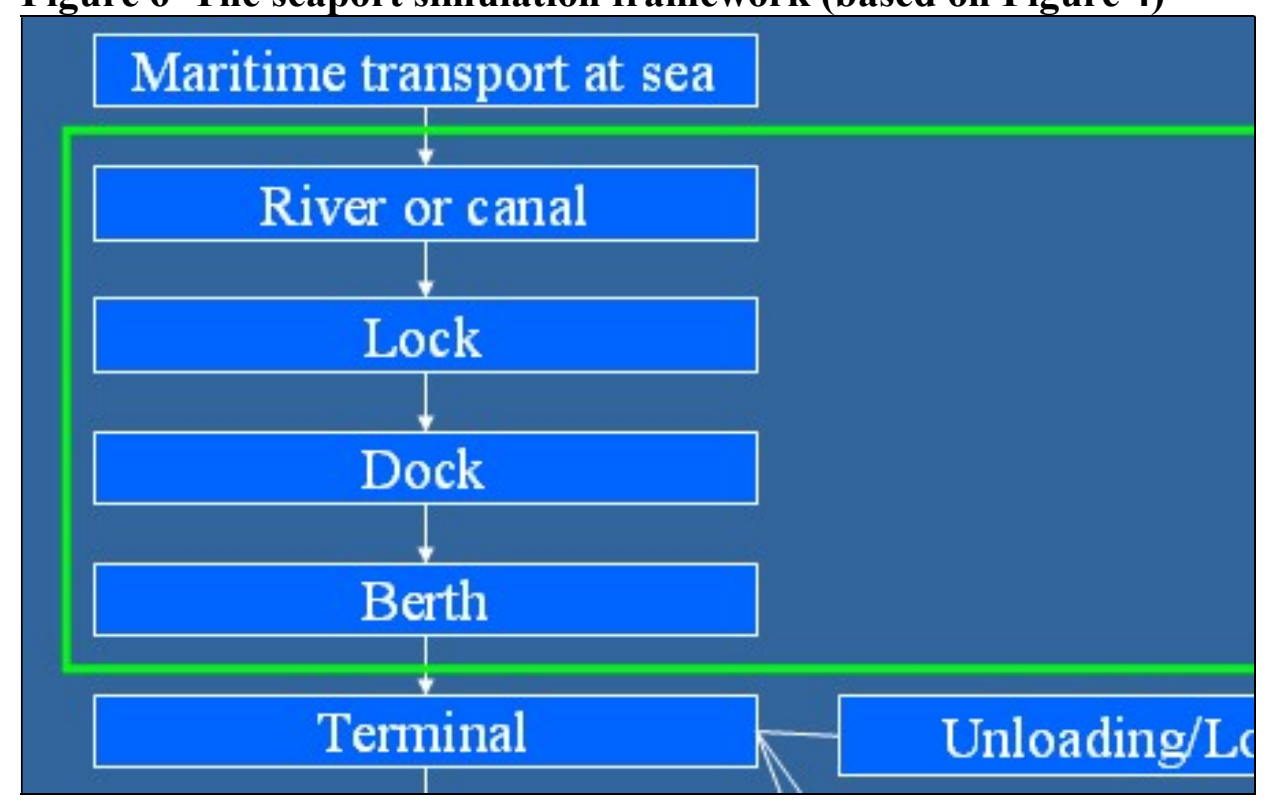

Source: own composition

The simulation tool is not specific for one port, but should be applicable to several ports. The main objective is therefore also defined as: "to assess marginal costs for different port and vessel types, according to a well-defined typology". For several ship typologies and several port typologies, marginal costs can be calculated. The construction of the simulation tool is based on an engineering approach and has been constructed in MS-OFFICE Excel.

In Figure 7, the decision process for the simulation tool is shown, containing possibilities when calling at a port. The maritime entrance buoy will be considered as the first point of contact with the port authorities. 
Figure 7 The decision process for the simulation tool

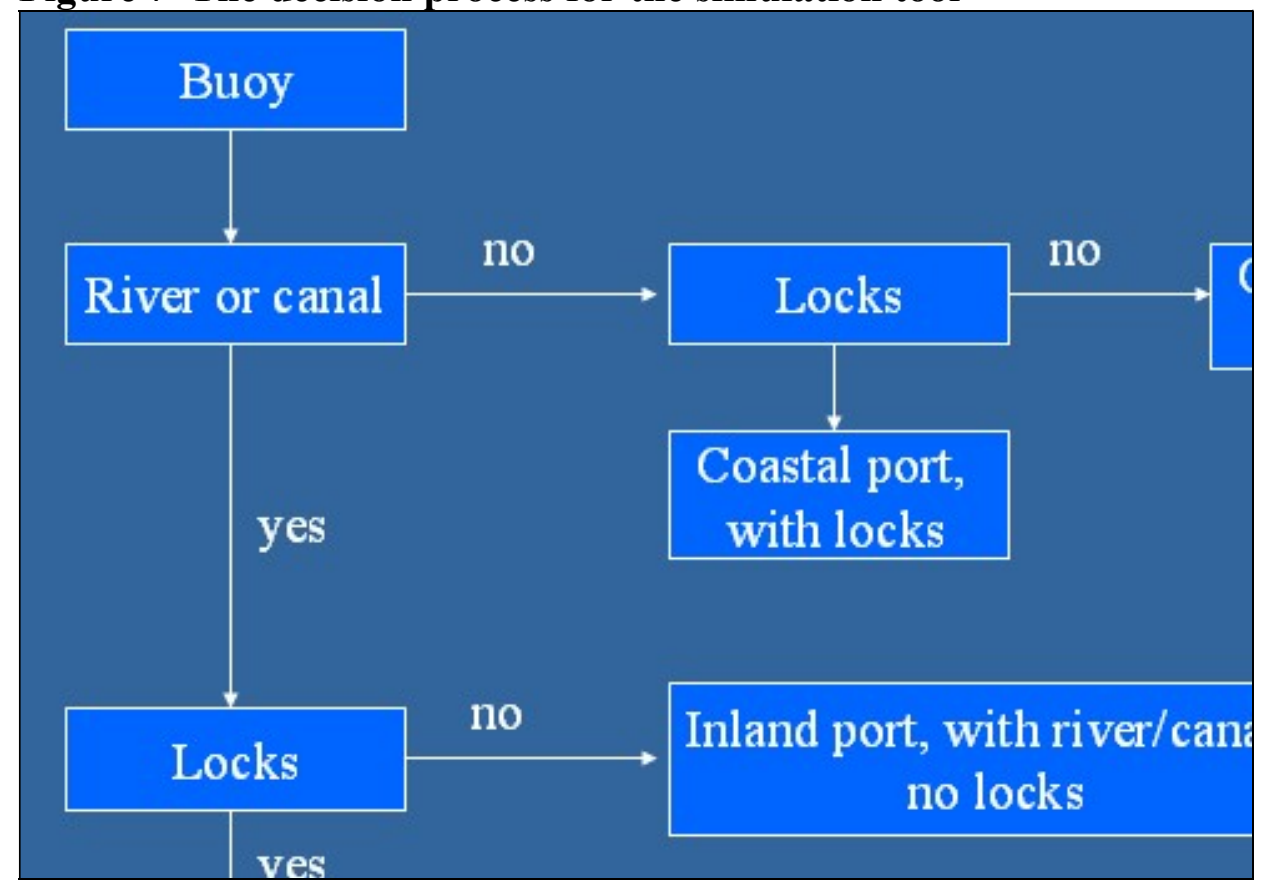

Source: own composition

Marginal costs are defined as those extra costs when a vessel is calling at a port or leaving a port. However, due to unavailability of some data, those marginal costs are sometimes approximated by average costs.

The four main marginal cost elements defined in section 3.2 (infrastructure, transport user, supplier/operator and external) are considered for a vessel on a specific link. The research is based on short-run marginal costs.

An example of SMC pricing in PPP is the use of locks in seaports. For example, the port of Antwerp is an inland tidal port using locks. Both banks of the Scheldt are used, with a phased development on the Left Bank. In order to have a second maritime entry on the left bank, the creation of a new lock is under consideration. Within the framework of this paper it could be argued to investigate a PPP formula for this lock in combination with the principle of SMC pricing.

In Meersman et al. (2006) a marginal infrastructure cost for the use of a lock has been estimated to be $€ 707$ per sea-going vessel. Table 9 gives an overview of the CAPEX of a new lock ( $€ 580,000,000$, prices of 2007) and the OPEX per year ( $€ 10,900,000$, prices of 2007). Considering a horizon of 50 years, this leads to total expenses of $€ 1,125,000,000$ (prices of 2007).

In a next step, we should determine the number of vessels using this lock. Starting from the observation of about 17,000 sea-vessels arriving in the port of Antwerp (Antwerp Port Authority, 2009), a number of scenarios can be calculated based on the share of vessels using the new lock (in Table 9: 100\%, 75\%, 50\% and 25\%). On the basis of the different assumptions, revenues based on SMC can be calculated (per year and for a period of 50 years). This leads to revenues ranging between $€ 600,950,000$ and $€ 150,237,500$. In some cases only $13 \%$ of the total expenses are covered. 
Table 9 Example of SMC pricing in PPP: the case of a new lock in the port of Antwerp (values in euro, prices of 2007)

\begin{tabular}{|c|c|c|c|c|}
\hline Expenses: & & & & \\
\hline Capex: & $580,000,000$ & & & \\
\hline Opex per year: & $10,900,000$ & & & \\
\hline Number of years: & 50 & & & \\
\hline Total Opex: & $545,000,000$ & & & \\
\hline Total expenses: & $1,125,000,000$ & & & \\
\hline $\begin{array}{l}\text { Number of maritime vessels in } \\
\text { Antwerp per year: }\end{array}$ & 17,000 & & & \\
\hline Revenues: & & & & \\
\hline Marginal infrastructure cost per vessel: & 707 & & & \\
\hline $\begin{array}{l}\text { Share of vessels using the new lock } \\
(\%) \text { : }\end{array}$ & 100 & 75 & 50 & 25 \\
\hline $\begin{array}{l}\text { Number of vessels using the new lock } \\
\text { per year: } \\
\text { Infrastructure cost per year when using }\end{array}$ & 17,000 & 12,750 & 8,500 & 4,250 \\
\hline the new lock: & $12,019,000$ & $9,014,250$ & $6,009,500$ & $3,004,750$ \\
\hline Number of years: & 50 & 50 & 50 & 50 \\
\hline Total revenues: & $600,950,000$ & $450,712,500$ & $300,475,000$ & $150,237,500$ \\
\hline Revenues - expenses: & $-524,050,000$ & $-674,287,500$ & $-824,525,000$ & $-974,762,500$ \\
\hline Revenues / expenses: & 0.53 & 0.40 & 0.27 & 0.13 \\
\hline
\end{tabular}

Source: own composition based on Gauderis et al. (2008)

Previous results are also in line with the findings in table 5. Low capacity utilization does not lead to full cost recovery, whereas high capacity utilization could lead to full cost recovery (in this case higher than expected).

Two remarks could be formulated on the basis of previous calculations:

- Locks in the port of Antwerp are also used by inland waterways, whereas the calculation of the marginal infrastructure cost in Meersman et al. (2006) only considers maritime vessels.

- The marginal infrastructure cost of $€ 707$ has been calculated on the basis of information of OPEX in the year 2006.

Therefore, two alternatives have been calculated in tables 10 and 11: doubling the marginal infrastructure cost and halving the marginal infrastructure cost. Even in the case of doubling the marginal infrastructure cost, only in the exceptional case of a share of $100 \%$ of the vessels using the new lock, the total expenses are covered.

It is shown in Meersman et al. (2006) that marginal infrastructure costs are only a small fraction of overall marginal costs, and fully depend on lock use: if no locks are used, no marginal infrastructure cost occurs. 
Table 10 Example of SMC pricing in PPP: the case of a new lock in the port of Antwerp (values in euro, prices of 2007) - doubling the marginal infrastructure cost

\begin{tabular}{|c|c|c|c|c|}
\hline Expenses: & & & & \\
\hline Capex: & $580,000,000$ & & & \\
\hline Opex per year: & $10,900,000$ & & & \\
\hline Number of years: & 50 & & & \\
\hline Total Opex: & $545,000,000$ & & & \\
\hline Total expenses: & $1,125,000,000$ & & & \\
\hline $\begin{array}{l}\text { Number of maritime vessels in Antwerp per } \\
\text { year: }\end{array}$ & 17,000 & & & \\
\hline Revenues: & & & & \\
\hline Marginal infrastructure cost per vessel: & 1,414 & & & \\
\hline Share of vessels using the new lock (\%): & 100 & 75 & 50 & 25 \\
\hline year: & 17,000 & 12,750 & 8,500 & 4,250 \\
\hline $\begin{array}{l}\text { Infrastructure cost per year when using the } \\
\text { new lock: }\end{array}$ & $24,038,000$ & $18,028,500$ & $12,019,000$ & $6,009,500$ \\
\hline Number of years: & 50 & 50 & 50 & 50 \\
\hline Total revenues: & $1,201,900,000$ & $901,425,000$ & $600,950,000$ & $300,475,000$ \\
\hline Revenues - expenses: & $76,900,000$ & $-223,575,000$ & $-524,050,000$ & $-824,525,000$ \\
\hline Revenues / expenses: & 1.07 & 0.80 & 0.53 & 0.27 \\
\hline
\end{tabular}

Source: own composition based on Gauderis et al. (2008)

Table 11 Example of SMC pricing in PPP: the case of a new lock in the port of Antwerp (values in euro, prices of 2007) - halving the marginal infrastructure cost

\begin{tabular}{|c|c|c|c|c|}
\hline \multicolumn{5}{|l|}{ Expenses: } \\
\hline Capex: & $580,000,000$ & & & \\
\hline Opex per year: & $10,900,000$ & & & \\
\hline Number of years: & 50 & & & \\
\hline Total Opex: & $545,000,000$ & & & \\
\hline Total expenses: & $1,125,000,000$ & & & \\
\hline $\begin{array}{l}\text { Number of maritime vessels in Antwerp } \\
\text { per year: }\end{array}$ & 17,000 & & & \\
\hline Revenues: & & & & \\
\hline Marginal infrastructure cost per vessel: & 353.5 & & & \\
\hline Share of vessels using the new lock (\%): & 100 & 75 & 50 & 25 \\
\hline year: & 17,000 & 12,750 & 8,500 & 4,250 \\
\hline $\begin{array}{l}\text { Infrastructure cost per year when using the } \\
\text { new lock: }\end{array}$ & $6,009,500$ & $4,507,125$ & $3,004,750$ & $1,502,375$ \\
\hline Number of years: & 50 & 50 & 50 & 50 \\
\hline Total revenues: & $300,475,000$ & $225,356,250$ & $150,237,500$ & $75,118,750$ \\
\hline Revenues - expenses: & $-824,525,000$ & $-899,643,750$ & $-974,762,500$ & $-1,049,881,250$ \\
\hline Revenues / expenses: & 0.27 & 0.20 & 0.13 & 0.07 \\
\hline
\end{tabular}

Source: own composition based on Gauderis et al. (2008) 


\section{PPP agreements as sources of alternative financing}

\section{1 The setting}

Investments in maritime entrance and port infrastructure involve very large amounts. That makes it difficult for a government to apply the traditional 'pay as you go' methods, among others since the available amounts per fiscal year are limited. Moreover, postponing projects and waiting till the necessary means are available leads to congestion and waiting times for potential users, as indicated in previous sections. The linked loss of competitive power in turn leads to potential welfare loss (Capka, 2006).

The traditional financing of port infrastructure works has reached its limits, especially because of limited financial means. To cover up for the lack of financing, more and more alternative financing methods are sought for. Globally, three typologies can be distinguished: ways of alternative financing that by the investing government is purely considered to be a financial operation; a non-financial PPP, and privatising infrastructure elements.

The Canadian Council for Public-Private Partnerships defines PPP agreements as follows: "A cooperative venture between the public and private sectors, built on the expertise of each partner, that best meets clearly defined public needs through the appropriate allocation of resources, risks and rewards" (CCCP, 2001).

The public and the private sector can co-operate on two areas, that can run over into each other. First of all, co-operation is possible in the financial domain, whereby the private partner $^{12}$ provides the total or part of the financing for constructing and maintaining the infrastructure. On the other hand, the private partner can cater for operating the infrastructure, without being responsible for financing that infrastructure. The underlying motive for cooperation between the public and the private sector is the fact that both sectors have unique features that can mean a surplus value for the project. But it goes without saying that, from a government point of view, the biggest motive for a PPP agreement lies in budgetary shortages, the old age of existing infrastructure, and the growing demand for public services. Bringing in a private partner moreover nearly always boils down to being able to finish a piece of infrastructure quicker, running that infrastructure in a better way, and/or taking advantage of the new, available innovative techniques.

A succesful PPP for a government means a lowering of financing costs and building new knowledge. Via a PPP agreement, the government aims at a bigger cost efficiency in buying and building infrastructure, not so much at owning and managing the assets directly. The private company, for that co-operation, receives a reward, and eventually generates also employment when able to build or manage the infrastructure project.

A PPP agreement so is about dividing the financial means, the risks and the returns between the private and the public sector. Each party is to bring in means, like financial means, expertise and fixed assets (e.g. land and material). Governments for instance can make available land for a certain infrastructure project, while the private sector brings in financial means. Via co-operation, the government also intends to lower own risks that are inherently linked to building new infrastructure. ${ }^{13}$ The higher the perceived risk that is being transferred

\footnotetext{
${ }^{12}$ In this text, we use the word 'partner' in single, knowing that in practice, several partners can be involved.

${ }^{13}$ The risks that public and private parties may face, consist of general risks (especially political and market risks) and project-specific risks (in particular the financial risk, the construction risk and the operational risk).
} 
to the private partner, the higher the required risk premium will be that the private partner will expect from the government. That same government can provide the private partner with future income in different ways: via the permit to levy a toll, via a shadow toll, or via a remuneration of availability.

\subsection{Different types of PPP agreements}

Different types of PPP structures exist, in function of the responsibility that the private partner bears. Options are carrying the financial risk, building, designing, managing or owning the infrastructure. Figure 8 gives an overview of the different options.

Figure 8: Types of infrastructure agreements

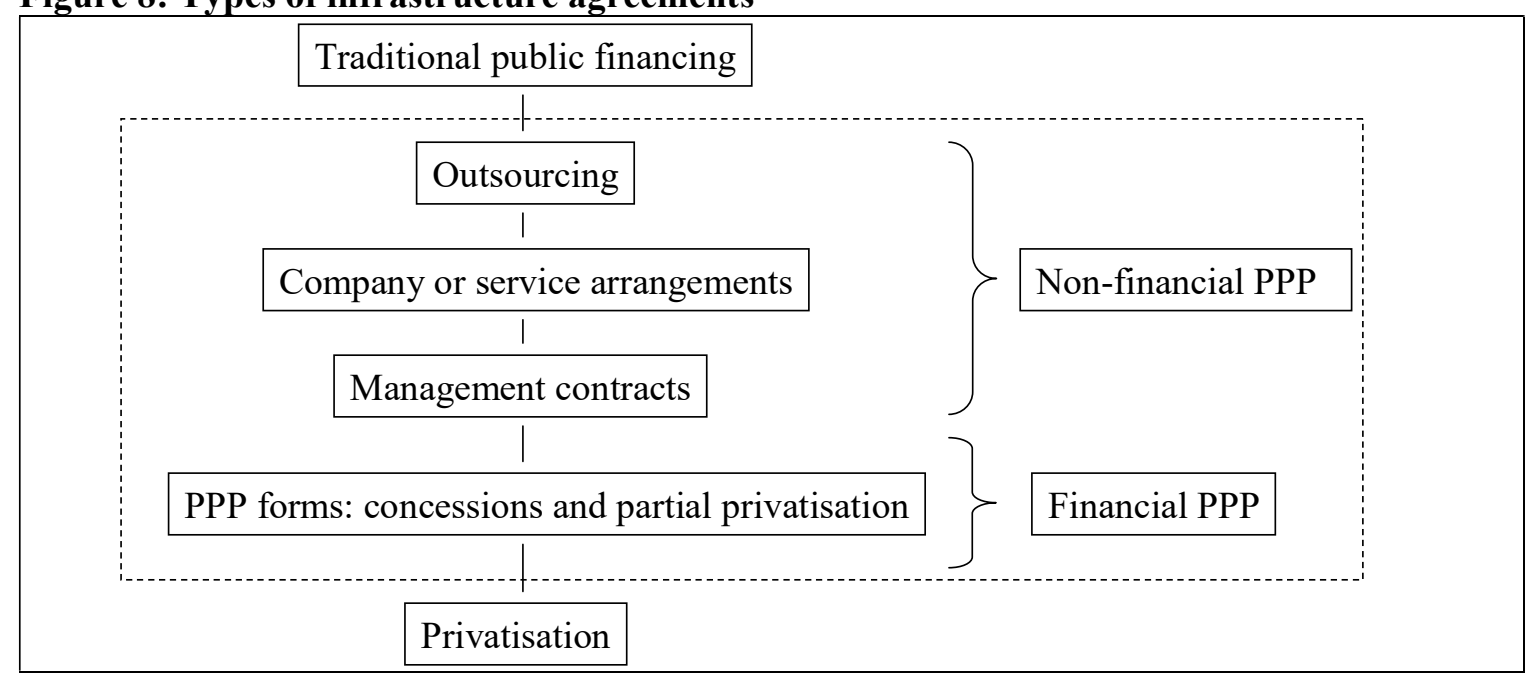

Source: based on Guasch, 2004

Under non-financial public-private co-operation, all forms of co-operation between both parties are comprised where the private partner provides no financial support to the public sector for building the infrastructure. The contribution of the private partner to the materialisation of the infrastructure can happen in different ways, among others via outsourcing, company and service arrangements and management contracts. This PPP form therefore provides no solution when the government is in search of alternative financing. (Worldbank, 2009)

With a financial PPP or Private Finance Initiative (PFI), the public sector takes the capital, that is necessary for buying or building the infrastructure from the private sector. Within PFI, one distinguishes among two important groups: the concession and the partial privatisation. The most complete PFI form, where the private sector takes over all tasks from the government, is the Design-Build-Finance-Operate-structure (DBFO). This structure encompasses all steps that are necessary to make the infrastructure project happen: designing, building, financing and managing. An alternative to this is the DBFMO (Design-BuildFinance-Maintain-Operate) structure. The private partner, next to designing, building, financing and exploiting the infrastructure, is also in charge of maintaining it. Over the years, many alternatives to this structure have been developed. ${ }^{14}$

\footnotetext{
14 The most well-known forms are Buy-Build-Operate (BBO), Build-Own-Operate-Transfer (BOOT), BuildTransfer-Operate (BTO), Build-Operate-Renewal (BOR), Wrapp around Addition, Lease-Purchase and SaleLease Back, Temporary Privatisation.
} 
Finally, there still is privatisation, where the full responsibility for a certain infrastructure project is transferred to the private sector. Privatisation is also known as Build-Own-Operate (BOO). The private partner has no obligation to transfer the infrastructure to the government, and the government has no obligation to re-buy that same infrastructure later on.

\subsection{PPP in port infrastructure}

In transportation in total, in the period 1990-2007, PPPs emerged in 81 countries, totalling 1,097 projects $^{15}$. The region with the largest share of transport PPP agreements is Latin America / Caribbean. Europe does not seem to have many PPP agreements in transport. The most frequent type of PPP agreements are concessions, also in Europe. Management and lease contracts are least used. The annual number of projects and their investment value does not seem to have changed much over the period. For seaports in particular, this would have been about 325 projects, having a project value of 41 bn USD. (Worldbank, 2009)

For the period 2005-2010, it is expected that about $10 \%$ of all PPP agreements in transportation will be in the seaport sector, involving private investments of about 19 bn USD, as shown in Figure 9. ${ }^{16}$ The share of seaports in PPP investments is therefore higher than its share in overall investments, which is $7 \%$. In transportation, rail represents the highest value of private investment volumes through PPPs, although in a number of projects, rail has about the same share as seaports. (Cheatham and Oblin, 2007)

Figure 9: The PPP pipeline

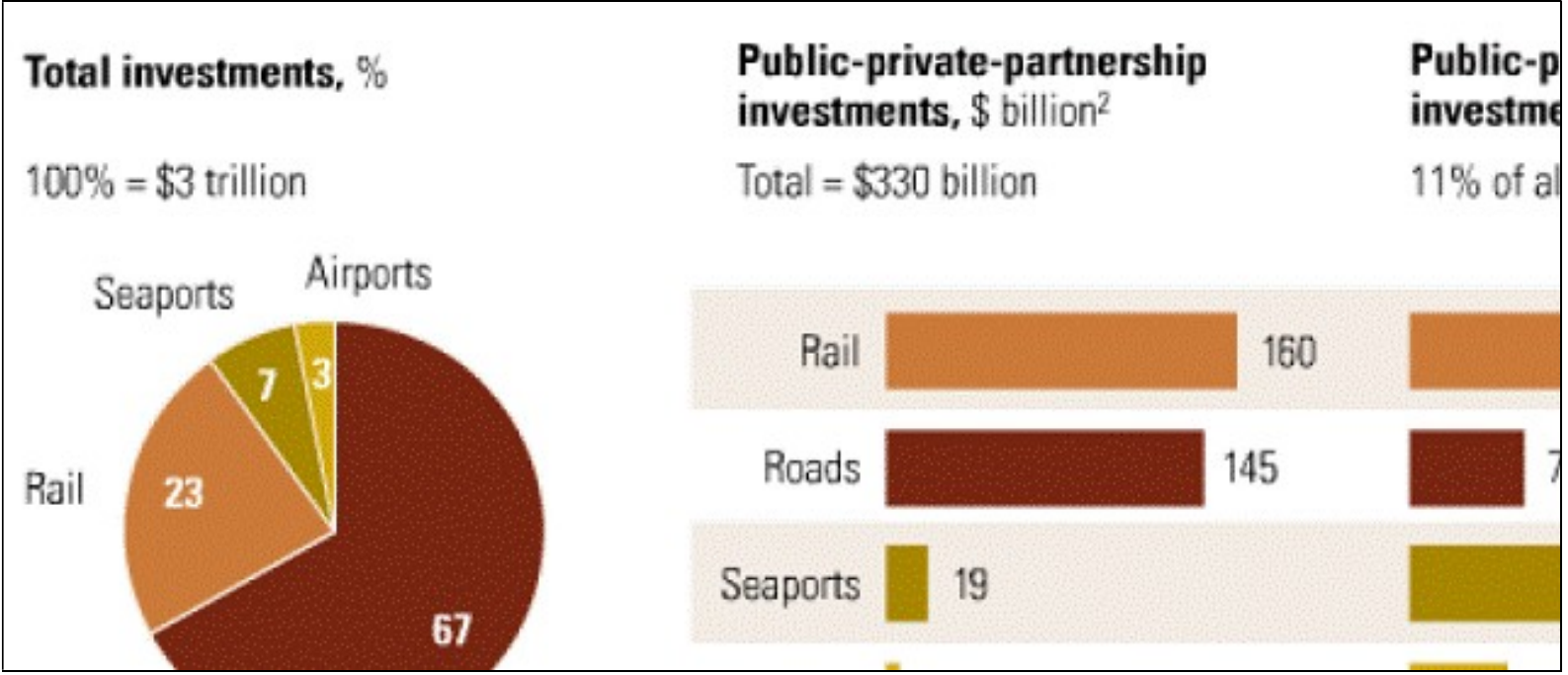

Source: Cheatham and Oblin (2007)

Geographically, it seems that Western Europe and the United States will have no PPPs in seaports over the period 2005-2010, as shown in figure 10. In East-Asia, seaports represent $4 \%$ in all transport PPP agreements, so that the rest of the world makes up for about $15 \%$ in all such agreements. (Cheatham and Oblin, 2007).

\footnotetext{
15 These figures involve projects that we registered by the Worldbank.

${ }^{16}$ Global total extrapolated from country date weighted by GDP. Countries included are Australia, Brazil, China, France, Germany, India, Italy, Japan, Portugal, Russia, South-Korea, Thailand, United Kingdom and United States. The breakdown by mode is not available for Australia and Portugal.
} 
Figure 10: The regional PPP landscape

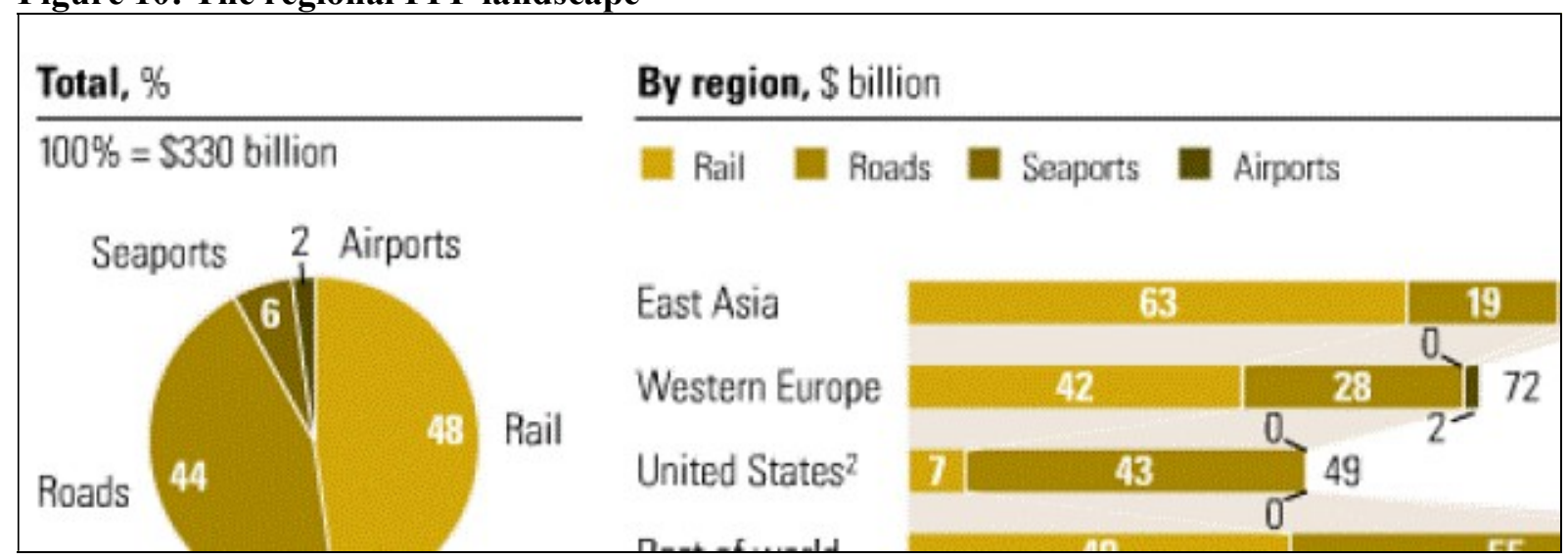

Source: Cheatham and Oblin (2007)

Where PPPs are applied in ports, they can take different forms. Land-lord seaport authority bodies belong to the type of port where the seaport authority least intervenes in operations. In these seaports, possession, occupation and use of property is transferred by the seaport authority institution to a potential user, in exchange for a payment or a rent. This arrangement usually takes the form of a lease, which can adopt three varieties: a land lease, a lease to operate, and a lease for building. (Asian Development Bank, 2000, p. 20)

- A land lease grants the concessionary the right to possess, use and operate a (mostly) 'naked' port area on payment of a 'fixed' concession duty (called a 'canon' by Trujillo and Nombela (1999, p. 26)). Examples of land leases are found for example in Antwerp, Singapore, Busan (among others at its Gamman terminal), Rotterdam, Los Angeles, Hamburg, Long Beach, Klang and New York (at Port Newark / Elizabeth Marine Terminal).

- In case of a lease to operate and manage, a management agreement transfers management and operation of a seaport site, its equipment and administration to a management company, against parting with a share of cargo handling charges. This construction was set up in Kingston (Jamaica), where the Kingston Container Terminal is owned by the Port Authority, but managed by APM Terminals.

- A lease to build makes the lessee financially responsible for all infra- and superstructure improvements and constructions, transferring these to the lessor (port authority) upon termination of the lease contract, but allowing the lessee to earn a toll on facilities constructed. The port of Hong Kong for instance applies the lease-to-build contract type among others at the Kwai Chung Terminal. Also at Busan, a lease-to-build contract is used for the development of the New Port Project. At Kaohsiung, part of container terminal $\mathrm{n}^{\circ} 5$ was leased out through BOT (Build-Operate-Transfer). The Yantian International Container Terminal development at Shenzen is equally performed under such BOT regime. In New York, the Global Marine Terminal was privately developed, and the South Brooklyn Terminal is to be developed under the 'lease to build' system.

Several types of conditions can be imposed on the lessee signing the lease contract. In Kochin for instance, DPA International in 2004 won a contract for building and operating the International Container Transhipment Terminal (ICTT), upon condition that at least 400,000 TEU be handled within 10 years after obtaining the ICTT lease contract at another container terminal in the port operated by DPA International; furthermore, operations should be fully shifted to the ICTT terminal within two years after starting construction there; the contract runs for 30 years (Manoj, 2004). Characteristics typically defined in concession contracts and limiting the lessee's degrees of freedom are length, ownership division, labour requirements, 
operational practices, pricing boundaries, investment requirements, financial performance indicators, liability and risk division, and arbitration terms (Estache et al., 2001, p. 3; World Bank, 2001c, p. 20-24; Crook, 2002, p.15 and Juhel, 2001, p. 166).

More port administration involvement than in land-lord seaport types is found in limitedoperating seaport authority bodies, in which the seaport authority institution provides equipment for operations. Cass (1999, p. 35) sees these as a variant of the land-lord type, where besides the seaport area also operational equipment is leased. Nevertheless, a contracting operator in a limited-operating seaport executes operations in his own name and commercial risk (like in a land-lord seaport), but under regulatory control and on account of the port authority (Trujillo and Nombela, 1999, p. 29-31). Such an operator can be granted a permit to operate a public utility, a permit to operate a private utility, or a joint venture contract. (Asian Development Bank, 2000, p. 20)

- A permit to operate a public utility allows the container-handling company to operate a public facility on account of the port authority. The incentive for investing is low though in case of permits to use public utilities, since this contract is merely about private or common utilities or specific services, not about site occupation, which is the case in the land-lord system. A permit to operate a public utility is in place for instance in Brest, where the Chambre de Commerce et d'Industrie granted a permit to three operators.

- A permit to operate a private utility has the operator build superstructure of his own, but still has him operate it on account of the administration. A permit to operate a private utility exists for instance in Caen, where Combustibles de Normandie operates a terminal under such regime.

- A joint-venture contract is often applied in case the operator has insufficient resources to equip the terminal himself. A joint-venture contract is applied for example in Qingdao, for creating the new Qingdao Qianwan Container Port Cy Ltd.

Under a comprehensive (or service, or operating) type of port authority, the seaport authority institution also takes care of operations, although contracts with companies are still possible, as is frequently the case for stevedoring activities. One example of a comprehensive (or service, or operating) type of port authority is Dubai where the Port Authority is assuming all functions from infrastructure provision to (un-)loading.

It should be noted that different organizational arrangements are applied to several terminals in the same port, even at the same time and to the same contractor. Dubai Ports Authority for instance won an operations contract for the existing Rajiv Gandhi Container Terminal in Kochi under a lease-to-operate concession (Manoj, 2004), and at the same time, it acquired a BOT contract in 2004 for the International Container Transhipment Terminal in the same port (The Hindu Online, 2004).

\subsection{The problem: SMC does not lead to cost recovery}

Overall, it seems that project numbers and investment volumes in seaport PPP agreements are going down. Europe and North America even feature no such agreements at all ${ }^{17}$. How can this observation be linked to the observations made in earlier sections?

From section 2, it can be learned that overall, SMC does not lead to recovery of fixed costs: only LMC would do so, because only in the long-run perspective, investments are included in

\footnotetext{
${ }^{17}$ According to the projects recorded by the Worldbank.
} 
the calculations. However, LMC has the disadvantage that in the short run, which in a port context can still be fairly long, it either leads to overcapacity or a shortage of such capacity. The reason is that under a certain seaport investment, in a situation of demand which is lower than expected, overcapacity will occur, which shows that the price asked was too high. When demand is higher than expected, a capacity shortage will occur, showing that the price asked was too low.

The fact that in ports, apart from the terminals, fixed cost investments are very substantial, and there is practically no way to allocate marginal effects per vessel, implies that values recovered from SMC in pricing in ports are extremely low. In no way can this be an attractive investment for private partners, who are constantly looking for profit and a sufficient return on investment.

This is slightly different in other modes of transport, where the marginal effect on investments, in particular infrastructure, is more easy to observe. In road and rail transport, wear and tear of infrastructure is quantifiable, and well-developed cost figures exist, based on widely spread and long lasting cost records. It is less the case in barge and air transport, and extremely so in the port sector.

It can be expected that for terminals, the situation is similar, as far as the infrastructure part is concerned. Matters are different for terminal operations, where a clear allocation of costs per vessel is possible, so that there is a higher tendency to apply marginal cost pricing. A factor which further compels to do so, is the strong competition within the terminal business, and the market power exerted by the shipping lines as customers.

As fixed investment volumes per project are only expected to further rise, if only for the side effects to be mitigated (environmental, social,...), it can be expected that the attractiveness of such port-related projects will not increase, on the contrary. 


\section{Conclusions}

From a theoretical perspective, SMC pricing is shown to be a well working principle, on condition that as many as possible of the activities have clearly attributable marginal effects. LMC pricing in general is said to be optimal for the average investment. However, in a port sector, with infrastructure investments that last for a very, very long number of years, applying LMC pricing would lead to either under- or overcapacity, which is not optimal from a welfare-economic point of view.

For stimulating private involvement in the port sector however, through PPP for instance, SMC would not be very helpful, since typically, only a very minor part of the investment would be paid for by the actual user. In no way can this be considered a profitable and attractive investment, especially when the non-terminal elements are considered.

This is also observable in the actual PPP agreements that were made in a port context: According to Worldbank data, Europe and North America feature none, and in the parts of the world where they are applied, the numbers of projects are low, and mainly focus on terminal investments.

When looking at the prices that are actually applied in the port sector, these seem to be far below the tariffs that should be asked when SMC would be applied. Even stronger, the rules and criteria applied when pricing vary very strongly between ports. No port resembles an other: not in the actual unit tariffs, and not in the categories and criteria applied. So there is a strong point for introducing marginal cost pricing.

How this could be done in a port context, was partly analyzed in this contribution, in a theoretical way for the entire port call stretch, and with actual calculated values for the use of locks when calling at a port. But for attracting PPP agreements, apparently, SMC would not help much. 


\section{References}

Adler, N., Nash, C. and E. Niskanen (2003), "Barriers to Efficient Cost-based pricing of Rail, Air and Water Transport Infrastructure in Europe", Paper presented at 4th IMPRINTEUROPE Thematic Networks, Brussels

Antwerp Port Authority (2009), www.portofantwerp.com

Asian Development Bank (2000), Developing Best Practices for Promoting Private Sector Investment in Infrastructure -- $\quad$ Port, $134 \quad$ p., http://www.adb.org/Documents/Books/Developing_Best_Practices/Ports/default.asp

Bennathan, E. and A.A. Walters (1979), Port Pricing and Investment Policy for Developing Countries, New York, Oxford University Press, 230 p.

Bickel, P., C. Certan, C. Doll, M. Gommers, P. Goyal, G. Lindberg, H. Link, R. Macario, T. Sansom, M. Van den Bossche (2000), Marginal Cost Methodology, Deliverable 3 of EC UNITE-research program, Leeds, $61 \mathrm{p}$.

Blauwens, G., De Baere, P. and E. Van de Voorde (2008), Transport Economics, Antwerp, De Boeck, 475 p.

Capka, J.R. (2006), Financing Megaprojects, Public Roads, Vol. 69(4), p. 2.

CCPP (2009), About PPP, The Canadian Council for Public-Private Partnerships, url: http://www.pppcouncil.ca/aboutPPP_definition.asp (consulted on 23 March 2009)

Cheatham, B. and W. Oblin (2007), Private-investment opportunities for public transport, McKinsey Quarterly April 2007

Crook, G. (2002), Infrastructures Framework for Trade

European Commission (1998), White Paper. Fair Payment for Infrastructure Use: A Phased Approach to a Common Transport Infrastructure Charging Framework in the EU,Brussels, EC, 56 pp., Com (98) 466

Estache, A., Gonzalez, M. and L. Trujillo (2001), Technical Efficiency Gains from Port Reform: The Potential for Yardstick Competition in Mexico, 20 p., http://econ.worldbank.org/files/2316_wps2637.pdf

Gauderis, J., Debisschop, K., Lyen, K., Jansen, B., Volgers, M. and R. Thomas (2008), Opmaak van een Geïntegreerde Maatschappelijke Kosten Baten Analyse (MKBA) Economische Effecten Analyse (EEA) voor een tweede maritieme toegang tot de Waaslandhaven en alle onlosmakelijk ermee verbonden inbegrepen - Eindrapport, Antwerpen

Guasch, G.L. (2004), Granting and Renegotiating Infrastructure Concessions: Doing it Right, The International Bank for Reconstruction and Development, The World Bank, Washington D.C. 
Haralambides, H.E., Verbeke, A, Musso E, and. Bennachio M. (2001), Port Financing and Pricing in the EU: Theory, Politics and Reality, The International Association of Maritime Economists, Annual Conference 2001: The Proceedings

Haralambides, H.H. and A.W. Veenstra (2003), Port Pricing, in: Grammenos, C.T. (ed.), The Handbook of Maritime Economics and Business, London and Hong Kong, LLP, pp. 782-802

Heggie, I.G. (1974), Charging for Port Facilities, Journal of Transport Economics and Policy, p. $3-25$

Huybrechts, M., Meersman, H., Van de Voorde, E., Van Hooydonk, E., Verbeke, A. and W. Winkelmans (Eds.), 2002, Port Competitiveness. An economic and legal analysis of the factors determining the competitiveness of seaports, Editions De Boeck Ltd., Antwerp

Juhel, M. (2001), Globalisation, Privatisation and Restructuring of Ports, International Journal of Maritime Economics, Vol. 3, n², pp. 139-174

Manoj, P. (2004), "Dubai Port Intl's acquisition of CSX World Terminals — A box of benefits for Kochi ICTT", The Hindu Business Line, http://www.thehindubusinessline.com/2004/12/20/stories/2004122000190600.htm

Meersman H. (1999), Maritime traffic and the world economy, Future challenges for the port and shipping sector, London, Informa, 2009, p. 1-25

Meersman, H., Van de Voorde, E. and T. Vanelslander (2009), Scenarios and strategies for the port and shipping sector, Future challenges for the port and shipping sector, London, Informa, 2009, p. 143-160

Meersman, H., Monteiro, F., Onghena, E., Pauwels, T., Van de Voorde, E. and T. Vanelslander (2006), Social marginal cost calculation for ports, in: GRACE Generalisation of Research on Accounts and Cost Estimation, Leeds, University of Leeds

Nationale Havenraad (2001), Nederland Havenland

Peston, M.H. and R. Rees (1971), Port Costs and the Demand for Port Facilities, London, National Ports Council, 52 p.

Pettersen-Strandenes, S. and P.B. Marlow (2000), "Port Pricing and Competitiveness in Short Sea Shipping”, International Journal of Transport Economics, Vol. XXVII, nr. 3, pp. 315-334.

Scheldt Information Centre (2006), http://www.waterland.net/sic/

Stopford, M. (2009), Maritime Economics (2nd ed.), Routledge

Strandenes, S. P. (2004), Port pricing structures and ship efficiency, Review of Network Economics, Vol. 3, issue 2, pp. 135-144

Suykens, F. and E. Van de Voorde (1998), A Quarter of a Century of Port Management in Europe: Objectives and Tools, Maritime Policy and Management, vol. 25, n 3, pp. $251-261$ 
Talley, W.K. (1994), Port Pricing: a Cost Axiomatic Approach, Maritime Policy and Management, London, 61-76

Tervonen, H., H. Metsäranta and A. Goebel (2001), Marginal Cost Charging in Finland, 92 p.

The Hindu Online (2004), Election Commission's clearance sought for Vallarpadam project, http://www.hindu.com/2004/04/09/stories/2004040905190300.htm

Trujillo, L. and G. Nombele (1999), Privatization and regulation of the seaport industry, in ESTACHE, Antonio and Ginés DE RUS (Eds.), Privatization and Regulation of Transport Infrastructure - Guidelines for Policymakers and Regulators, The World Bank Institute

Vanelslander Thierry (2005), The economics behind co-operation and competition in sea-port container handling, Antwerpen, University of Antwerp, $241 \mathrm{p}$.

Wijnolst, N. and T. Wergeland (1997), Shipping, Delft, Delft University Press, 595 p.

Worldbank (2001), Port Reform Toolkit - Module 4: Legal Tools for Port Reform, 73 p., http://www.worldbank.org/transport/ports/toolkit/mod4.pdf

Worldbank (2009), Private Participation in Infrastructure Database, http://ppi.worldbank.org 